\title{
40. PALEOENVIRONMENTAL STUDY OF BARREMIAN-ALBIAN SEDIMENTS AT DEEP SEA DRILLING PROJECT SITE 549 IN THE EASTERN NORTH ATLANTIC ${ }^{1}$
}

\author{
Pierre Rat, Eric Gillot, Françoise Magniez, and André Pascal, Institut des Sciences de la Terre, \\ Université de Dijon²
}

\begin{abstract}
This study is devoted to the lower series (Barremian-lower Albian) of Hole 549, just west of the continental shelf of northwestern Europe (Leg 80 of DSDP-IPOD). The lithological analysis is correlated with downhole logging, X-ray mineralogy, foraminiferal assemblages, and biological content. Biosedimentary environments and general pattern of distribution are interpreted and compared with Cretaceous exposures of northern Spain.

Two successive paleogeographic phases are identified: a short transgressive episode giving a shallow environment (Barremian), and the opening (lower Albian) of a long period of pelagic sedimentation in a bathyal environment. They were separated by a gap in deposition, so that the record of intervening events is lost.

The lower series begins with a record of marine transgression. The sporadic occurrences of oysters indicate a lowering of salinity. As the transgression became more extensive, the sediments became more calcareous, forming part of a carbonate platform. Trocholina species are associated with encrusting and other benthic foraminifers, bryozoans, corals, and algae. Subsequent deposition could not keep pace with subsidence, and the water deepened, as indicated by the presence of the planktonic foraminifer Hedbergella in association with small benthic foraminifers in a clayey-silty sediment interpreted as a quiet muddy seafloor. Clastic material is very mature, implying provenance in a very weathered area. In the lower part of the column kaolinite was the main mineral in the fraction smaller than $2 \mu \mathrm{m}$. In the carbonate sediments, kaolinite has been replaced by smectite.

The second phase is characterized by planktonic foraminifers of the genus Hedbergella and by radiolarians, reflecting increased subsidence and bathyal conditions.

The general trend of this evolution is chronologically in accordance with that known from the southern margin (Spain margin) of Biscay Bay.
\end{abstract}

\section{INTRODUCTION}

Four sites were drilled during Leg 80. Material from the lower part of Hole 549 was studied by our team. Hole 549 is located at $49^{\circ} 05.28^{\prime} \mathrm{N}, 13^{\circ} 05.88^{\prime} \mathrm{W}$. Drilling was initiated at $2533 \mathrm{~m}$ below sea level and penetrated $965 \mathrm{~m}$ of sediment ranging in age from Barremian to Quaternary before Hercynian basement was reached. (Fig. 1).

The post-Hercynian series begins with marine formations dated by study of their foraminifers as Barremian (Magniez and Sigal, this vol.). These formations are the main object of this study. A sediment gap (very likely including part of the upper Barremian, the Aptian, and part of the lower Albian) separates these marine formations from the next formation upsection (Albian), which has also been examined, more briefly, in order to follow the evolution of the sedimentary pattern from Lower to middle Cretaceous until a pelagic facies appears.

The aim of this work is essentially to discover the environments and sedimentary pattern by a threefold approach of sedimentology, mineralogy, and paleoecology, then to go further in their interpretation with the help of comparable data from the Cretaceous outcrops in northern Spain.

\footnotetext{
${ }^{1}$ Graciansky, P. C. de, Poag, C. W., et al., Init. Repts. DSDP, 80: Washington (U.S. Govt, Printing Office).

Address: Institut des Sciences de la Terre, Laboratoire associé au CNRS no, 157, Université de Dijon, 6 Bd. Gabriel, 21100 Dijon, France.
}

\section{LITHOLOGIC SUCCESSION}

The lithologic succession is shown in Figures 2, 3, and 4 (Fig. 4 back pocket). All the material studied contains a terrigenous fraction, sometimes inconspicuous, and a carbonate phase of sedimentary or diagenetic origin. The clastic terrigenous part is mainly silt-size particles (quartz and a few feldspars and micas). The carbonate phase is composed of bioclasts, in places extremely varied, and a microsparitic, micritic, or sparitic matrix visible in the most calcareous beds.

The terrigenous-to-carbonate ratio, the biological content, the arrangement in well-defined beds or lack of such arrangement, and the grain size of the terrigenous clastic material allow division of the succession into five formations, dated according to their microfauna (Magniez and Sigal, this vol.). These formations are described from the bottom of the hole upward.

\section{Unit E: Transgressive Terrigenous Formation}

This unit is dominantly terrigenous, with generally well sorted clastic particles: siltstones, claystones, sandstones with carbonate cement, and bioclastic siltstone lying in well-defined, approximately 1 -m-thick beds. Very calcareous beds rarely occur, and always contain terrigenous material.

A further division can be made into four members according to the frequency of calcareous interbeds and some additional criteria. Terrigenous arrivals are coarser at the bottom (Subunit E4), gradually become finer 


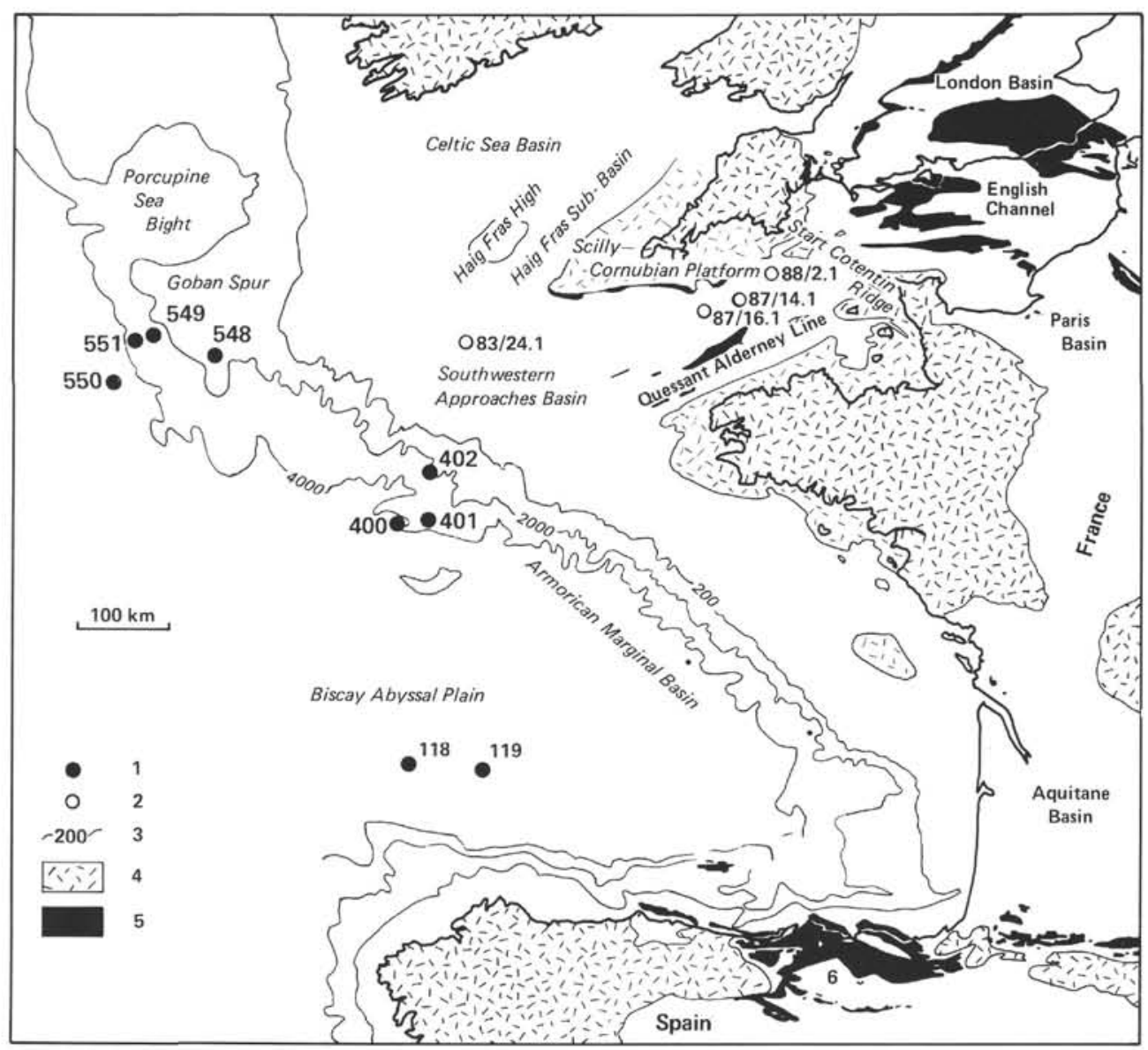

Figure 1. General physiography and partial seabed geology of the south-western European continental margin. Key to symbols: $1=$ locations of DSDP sites, $2=$ locations of Zephyr wells, $3=$ continental shelf edge, 4 = pre-Permian and Permotriassic basement, $5=$ Lower Cretaceous, $6=$ Basco-Cantabrian country. (From Montadert et al., 1979; Evans et al., 1981; Carte géologique de la France et de la marge continentale, BRGM, 1980). Bathymetry in meters.

upsection (Subunits E3 and E2), with more homogeneous and thicker beds in Subunit E2, and then coarsen again in Subunit E1. The biological content, very low in Subunit E4, comprises chiefly remains of marine organisms (shell debris, fragments of echinoderms, sponges, worm tubes, calcareous matter, and plant debris). The amount of organic matter decreases upsection. Foraminifers occur already in Subunit E4 (Core 549-93) but become numerous only in Core 549-91 (Subunit E3), which contains Choffatella assemblages. In Cores 549-78 and 549-79 (Subunit E1), the number of Trocholina slightly increases, announcing the Trocholina assemblages of the overlying Unit D.

\section{Subunit E4: Lower Detrital Member}

Depth: $965-941 \mathrm{~m}$

Thickness: $24 \mathrm{~m}$

Lithology: sandstones, siltstones, claystones, silty limestones

Age: Barremian

Alternating sandstones, siltstones, and claystones lie in 10-cm- to 1-m-thick beds, varying from yellow gray to dark brown. Their clastic terrigenous phase is composed mainly of quartz with a few feldspars, micas, chlorites, and heavy minerals (zircon, tourmaline), in a carbonate microsparitic and micritic matrix where it is visible in thin section (sparitic in Core 549-93). The sandstone beds from the lower part have a high intergranular porosity, secondary dolomitization having taken advantage of the voids. Some of these intergranular spaces are filled with a very dense micrite studded with dolomite rhombs.

Organic matter (plant debris) and pyrite are very abundant. The percentage of carbonate grains is very low, less than $5 \%$ on an average: shell debris, fragments of echinoderms (Core 549-93), bryozoans, algae, and worm tubes. There are various lithoclasts, originating from the basement and also from claystones.

As regards silty limestones, they are very rare, dark or olive-gray beds with many large shell fragments. The shipboard report mentions the existence of a hard sideritic bed in Core 549-92. Foraminifers occur rarely (agglutinated encrusting forms).

\section{Subunit E3: Silty and Bioclastic Member}

Depth: $941-884 \mathrm{~m}$

Thickness: $57 \mathrm{~m}$ 


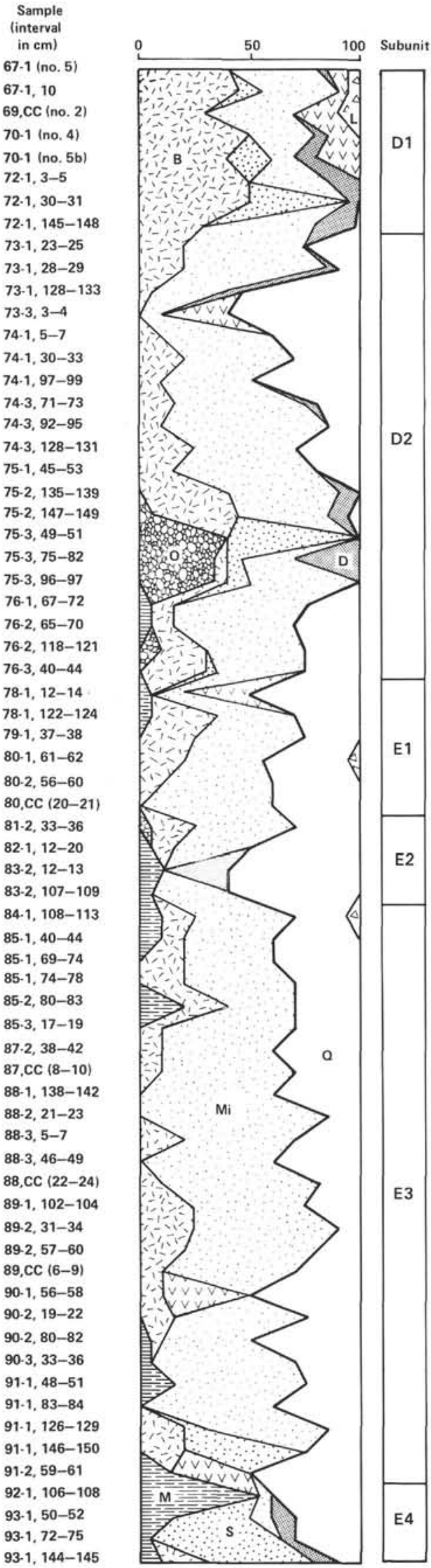

Sample

(interval

in $\mathrm{cm}$ )

36-1, 22-24

$37 \cdot 2,29-32$

$38 \cdot 1,31-34$

39.1, $1-3$

40-1, 3-6

42-1, 61-64

42-2, 34-37

43-1, 31-34

43-2, 10-14

43-2, 77-80

45-1, 59-62

45-2, 75-78

45-3, 41-44

$45-4,35-39$

$45.5,41-45$

46- $1,18-20$

$46 \cdot 2,98-100$

46-3, 29-31

$46-4,81-89$

47-1, 42-44

$47 \cdot 2,83-85$

47-3, 93-95

$47 \cdot 4,73-75$

47-5, 72-75

48-1, 29-31

52-1. 5-9

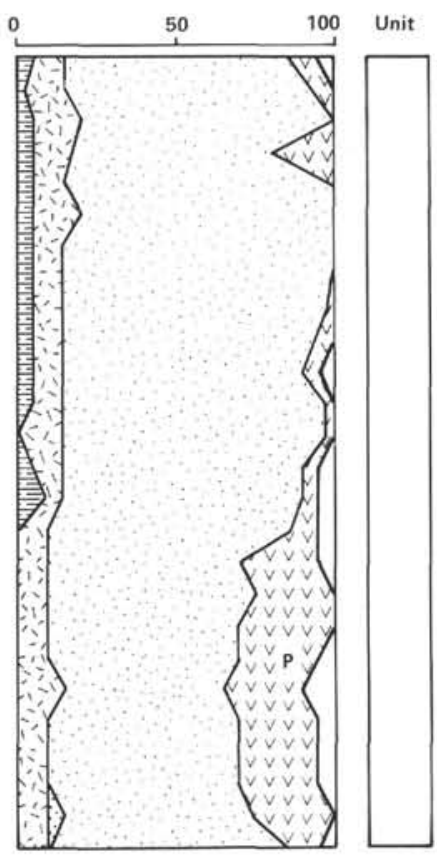

$54-3,119-123$

$55 \cdot 2,58-60$

55-2, 111-113

55-4, 118-120

56-2, 47-49

56-4, 35-37

57.1, 25-26

57.1, 134-135

$57-2,128-130$

57.3, 94-96

57-3, 123-125

58-3, 149-150

58-5, 65-67

58.5, 129-131

58-7, 25-27

$58, \mathrm{CC}$

59-1, 125-130

59-2, 130-137

60-1, 74-77

60-4, 88-91

$60.5,1-5$

60-5, 100-102

$60-5,122-124$

60-6, 68-70

61-1, 34-36

61-2, 94-96

61-2, 129-131

$61.2,140-150$

61.3, 14-16

61-3, 110-112

61-4, 28-31

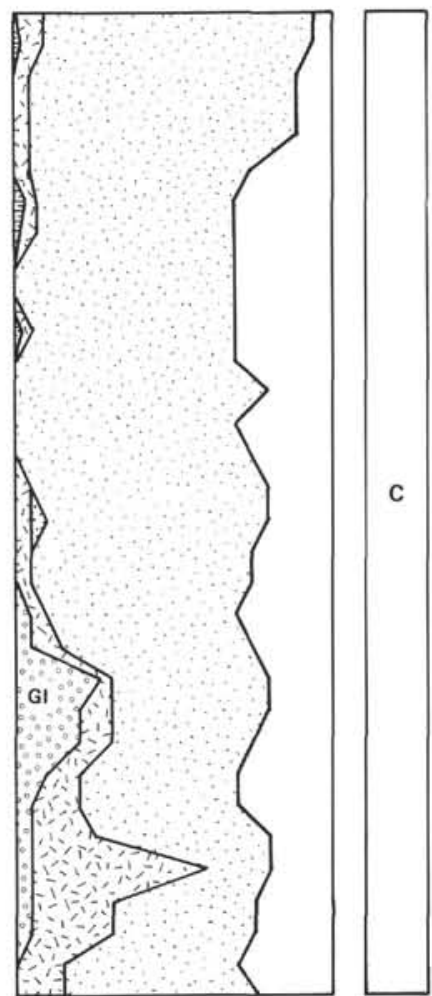

Figure 2. Compositions of the samples observed in thin section. No vertical scale. $\mathrm{B}=$ bioclasts, $\mathrm{D}=$ dolomite, $\mathrm{Gl}=$ glauconite, $\mathrm{L}=$ calcareous lithoclasts, $\mathrm{M}=$ organic matter and pyrite, $\mathrm{Mi}=$ microsparite and micrite, $\mathrm{O}=$ oncolites and/or oolites, $\mathrm{P}=$ porosity, $\mathrm{Q}=$ quartz, $\mathrm{S}=$ sparite. 


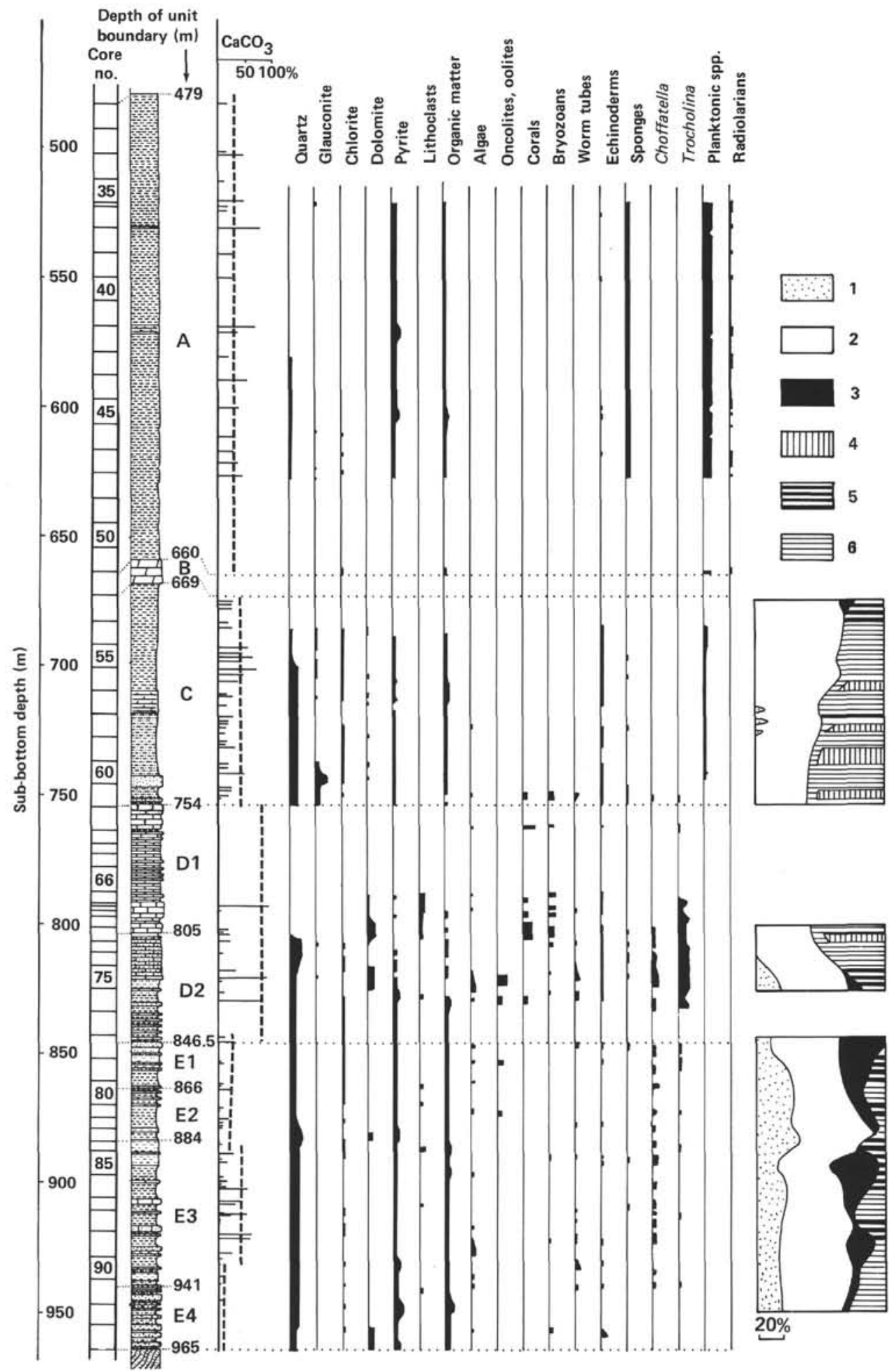

Figure 3. Lithological succession with mineral and paleontological data. $\mathrm{CaCO}_{3}$ content: from analysis (horizontal lines) and average estimates based on thin-section study (vertical interrupted line). Clay minerals: 1 = kaolinite, 2 = illite, $3=$ chlorite, $4=$ smectite, $5=$ mixed-layer minerals $(14 \mathrm{c}$ predominant member), $6=14 \mathrm{~m}$ predominant member. 
Lithology: bioclastic siltstones, silty bioclastic limestones, sandstones, claystones

Age: Barremian

Silty bioclastic limestones are commoner than in the preceding subunit but still less important than bioclastic siltstones. There is much bioturbation, but it has not destroyed all the sedimentary structures. Some beds are slightly laminated; often siltstone grades into claystone (Sections 549-86-1, 549-88-2, 549-88-3, 549-89-2, 54990-1, and 549-90-2). Contacts between beds are sharp, sometimes erosional, and overlain by mud clasts (Core 549-86). Bedding is clear but without any apparent sequences. The percentage of calcium carbonate varies widely from one layer to another, and on average it is higher than in E4 $(30 \%)$.

Bioclastic siltstones have a silty phase consisting mostly of well-sorted quartz, and a limited biological content: shell fragments, Choffatella, bryozoans, worm tubes, algae, and, exceptionally, charophyte oogonia (Sections $549-89-1$ and $549-88, \mathrm{CC}$ ). The matrix is micritic to microsparitic and rich in carbonaceous matter (plant debris) and pyrite.

In silty bioclastic limestones, the increasing size of the transported components indicates conditions of higher energy. Bioclasts are varied and numerous. To Choffatella are added small calcareous microgranular and porcellaneous foraminifers and, in the facies of highest energy, some Trocholina.

Some sandstone beds are revealed by well-logging. They can be up to $1 \mathrm{~m}$ thick in Core 549-89. Claystones are rare, and lie at the tops of graded beds. They contain practically no carbonate.

\section{Subunit E2: Calcareous Siltstone Member}

Depth: $884-866 \mathrm{~m}$

Thickness: $18 \mathrm{~m}$

Lithology: calcareous siltstones, bioclastic siltstones

Age: Barremian

This unit consists mainly of siltstones with a variable carbonate content, which, on the whole, is lower than in Subunit E3. These siltstones often show bioturbation and, in Core 549-82, some parallel or distorted laminations. They are often oxidized (Core 549-83), and vary greatly in color: green, olive-gray, blue, brown, red, reddish brown, yellow, rosy orange. The silty phase comprises mostly quartz. The matrix is microsparitic with some dolomitized patches in Section 549-83-2. Rare bioclasts are small-sized debris, the greatest part of which is transformed into sparite, fragments of echinoderms, and some calcareous algae. Of pyrite and plant debris there are only traces.

Bioclastic siltstones were noted in two places: Cores 549-82 and 549-81. They include much shell debris: lamellibranchs, brachiopods and gastropods, Choffatella, and very scarce oncolites with encrusting Girvanella at $549-81-2,33-36 \mathrm{~cm}$.

\section{Subunit E1: Upper Detrital Member}

Depth: $866-846.5 \mathrm{~m}$

Thickness: $19.5 \mathrm{~m}$
Lithology: sandstones, siltstones, bioclastic siltstones, silty limestones

Age: Barremian

Carbonate sandstones and bioclastic siltstones are interbedded. According to their calcium carbonate content, sandstones and siltstones appear in a succession of either light or dark gray bands. There is little bioturbation. Contacts between beds are sharp, sometimes erosional (Core 549-79). Sections 1 and 2 of Core 549-80 show some distorted laminations.

Sandstones and siltstones have very few bioclasts. Cement is microsparitic with trace amounts of pyrite and organic matter concentrated in thin layers.

More calcareous beds (bioclastic siltstones, silty limestones) contain some oncolites and more varied bioclasts: mostly shell debris, echinoderms, sponges, calcareous algae, worm tubes. Pure limestone is exceptional (peloid limestone in Core 549-79). Foraminifers are more diversified than in Subunit E2. The population of Choffatella plus Trocholina marks the transition to the overlying Subunit D2.

\section{Unit D: Calcareous Trocholina Formation}

Although recovery was poor, limestone beds appear dominant, on the basis of downhole logs. Benthic organisms play a prominent part. The sediments are not quite free from terrigenous material, however, especially in the lower half of the unit, where limestones contain an important silty phase (silty limestones), which sometimes prevails (bioclastic siltstones). Therefore, two subunits, D1 and D2, can be defined.

\section{Subunit D2: Silty Bioclastic Member}

Depth: $846.5-805 \mathrm{~m}$

Thickness: $41.5 \mathrm{~m}$

Lithology: siltstone, bioclastic siltstone, silty limestone, oncolitic grainstone

Age: Barremian

Siltstones have a very low carbonate content, sometimes less than $5 \%$. They are gray. The silt fraction, which makes up 50 to $60 \%$ of the rock, is mostly quartz, with a few feldspar and mica grains. Bioclastic components (shell debris) are scarce. Intergranular filling is varied, generally microsparitic, but sometimes sparitic or micritic.

Bioclastic siltstones and silty limestones are interbedded with siltstones. No sedimentary structure is clearly visible, because of intense bioturbation. Groundmass is mostly microsparitic with a few thin sparitic intercalcations and rare areas of secondary dolomitization. The silty part is mostly quartz. Bioclasts range from $40 \%$ in silty limestones to $10 \%$ in bioclastic siltstones: shell debris, fragments of echinoderms, worm tubes, bryozoans, sponges, and, for the first time, coral fragments (Section 549-76-2). In places there are also a few oncolites. The population of foraminifers is dominated by large Trocholina associated with Choffatella and rather numerous calcareous agglutinated species.

One remarkable limestone bed, made up of oncolites and foraminifers, occurs in Core 549-75. Oncolites, sev- 
eral millimeters in diameter, are coated with algae of the Girvanella type among many encrusting agglutinated and porcellaneous foraminifers. Cement is spar to microspar with patches of secondary dolomitization or geotropic micritic filling.

\section{Subunit D1: Bioclastic Limestone Member}

Depth: 805-754 m

Thickness: $51 \mathrm{~m}$

Lithology: bioclastic limestone, claystone

Age: Barremian

Bioclastic limestone-chiefly grainstone, exceptionally rudstone (Cores 549-67, and 549-71), and, to a lesser degree, packstone and wackestone (Core 549-72) - prevails. In the sedimentary grains, the percentage of bioclasts is variable but usually about $50 \%$ : bryozoans, which may even characterize some beds (bryozoan limestone in Core 549-70), lamellibranchs, brachiopods, gastropods, numerous coral fragments, worm tubes, and calcareous algae. Some of the grains have an organic coating. Benthic foraminifers are well diversified, and include encrusting forms, Trocholina, and, very seldom, orbitolinids (Core 549-70).

The relative abundance of calcareous lithoclasts (intra- and extraclasts) at the top of the subunit indicates higher water energy. Spar to microspar cements, with only micrite traces, also indicate winnowing.

As regards diagenesis, intergranular porosity is high. Scattered patches of dolomite were observed.

Terrigenous clastic material is missing in carbonate facies. It reappears, however, in thin, well-individualized layers, mostly argillaceous and slightly disturbed by synsedimentary microfaults.

\section{Unit C: Calcareous Silty Formation with Mixed Benthic and Planktonic Fauna}

\section{Depth: 754-669 m}

Thickness: $85 \mathrm{~m}$

Lithology: calcareous siltstones, sandy siltstones

Age: Barremian

Separation from Unit $D$. In Unit C, clastic terrigenous material (silt and clay) is again dominant, and planktonic foraminifers occur. The distinction between Units D and C is based upon a renewal of terrigenous influx. According to gamma-ray logging and the sonicvelocity curve, the boundary is located in a part which has not been recovered, approximately $754 \mathrm{~m}$ sub-bottom.

The base of the recovered part, however (Cores 54961 and 549-60), is somewhat different from the rest. It contains a notable amount of glauconite. In Core 54961 , planktonic foraminifers are missing. On the other hand, ataxophragmiids are abundant, Trocholina and Choffatella occur sporadically, and bioclasts are numerous and varied; these last features relate the base of Unit $\mathrm{C}$ to Unit D. The beds at the bottom of Unit C may contain reworked elements of underlying Subunit D1.

Glauconite layers. The occurrence of granular glauconite in the lowest part of Unit C (Core 549-60 to Core 549-61) is noteworthy. Glauconite grains give these layers a sandy appearance. On average they are larger than the quartz grains (up to $0.7 \mathrm{~mm}$ ). They are light green to olive-green, generally cracked, with numerous marks of oxidation (goethite). Some are internal moulds of foraminifers.

Variations in the silty series. The remainder of the unit is silty and more homogeneous. Its terrigenous content becomes finer from bottom to top, essentially because the silt fraction decreases, approximately from 30 to $10 \%$. A nannofossil chalk interbed in Core 549-57 (shipboard report) could mark a division into a lower part, more silty on the whole, and an upper part, more clayey.

More or less carbonate-rich layers ( 80 to $15 \%$ ), $10 \mathrm{~cm}$ to $1 \mathrm{~m}$ thick, alternate. Small bioclasts are concentrated in lighter-colored, more calcareous beds. Matrix is microsparitic to micritic, with a notable amount of organic matter and pyrite. Color varies from dark gray and light gray to yellow, brown, and even red under the contact with Unit B.

Biological content. Bioclasts are shell and echinoderm debris and sponge spicules. Hedbergella specimens appear at the top of Core 549-61. Small and scarce practically throughout the whole unit, they develop at the top (Core 549-55). They are associated with varied little benthic forms. Belemnite fragments were noticed in Cores 549-60, 549-55, and 549-53.

\section{Unit B: Dolomitic Formation}

Depth: $669-660 \mathrm{~m}$

Thickness: $9 \mathrm{~m}$

Lithology: dolomitic sandstones, claystones

Age: unknown (Aptian? Early Albian?)

We had no sample for this unit. Quartz grains are cemented by dolomite and silica (shipboard report). Downhole measurements indicate a discontinuity at the top: a thin layer, probably clay, marks the boundary with overlying Unit A (Borkowski and Mazzullo, this vol.).

\section{Unit A: Planktonic Marl Formation}

Depth: 660-479 m

Thickness: $181 \mathrm{~m}$

Lithology: marls with more or less silt and clay. Nannofossil limestones.

Age: early and middle Albian

Compact $\left(40 \% \mathrm{CaCO}_{3}\right)$, light-colored layers alternate with softer, less calcareous $\left(20 \% \mathrm{CaCO}_{3}\right)$, dark gray layers. These lie over the light-colored layers with a generally sharp contact, but no erosional marks have been recorded (shipboard report). In turn, darker layers grade into the lighter ones within a few centimeters. Thin sections show numerous planktonic organisms, foraminifers (Hedbergella) and radiolarians, sponge spicules, shell debris, and a few echinoderm fragments in a micritic matrix. The clastic terrigenous elements are siltsize and scarce (less than 10\%). Light-colored laminae, rich in microfossils, alternate with dark ones, dominantly argillaceous. In the dark layers, lamination is often disturbed. Thus, it seems that sedimentation rhythms exist on two scales: a centimetric one (lamination) and a decimetric one.

More calcareous $\left(70-80 \% \quad \mathrm{CaCO}_{3}\right)$ nannofossil layers, 0.40 to $2.60 \mathrm{~m}$ thick, have been found (shipboard 
report). These are light to dark gray, and, although rather homogeneous, they also show a slight lamination disturbed by bioturbation. Many sparitized shell bioclasts, radiolarians, sponge spicules, and planktonic foraminifers are scattered in a micritic matrix. Pyritic organic matter occurs.

\section{X-RAY MINERALOLOGY}

\section{Methods and Codification}

Sixty samples from the Barremian units $(E$ to $C)$ were analyzed with an X-ray diffractometer to obtain semiquantitative determinations of the mineral composition of the $<2 \mu \mathrm{m}$ fraction and of some whole rocks (see Thiry and Rat, this vol.).

Briefly, the method was as follows. Samples were crushed and decarbonated in N/10 hydrochloric acid. The excess acid was removed by successive centrifugations. The $<2 \mu \mathrm{m}$ fraction was collected by decantation and saturated with $\mathrm{Mg}$ (by $\mathrm{MgCl}_{2}$ solution), and then oriented aggregates were prepared on glass slides.

A Geigerflex Rigaku X-ray diffractometer with cobalt Fe-filtered radiation was used to run three scans, as follows: (1) from 3 to $33^{\circ}$ on normal untreated material, $\mathrm{N}$; (2) from 3 to $24^{\circ}$ after ethylene-glycolation, EG: (3) from 3 to $17^{\circ}$ after heat treatment to $490^{\circ} \mathrm{C}, \mathrm{CH}$. In addition, the Hofman-Klemen test (HK) was used to ascertain the compositions of smectites.

Mineral identifications were made on the basis of the three main peaks on diffraction patterns. Semiquantitative estimates were obtained by using peak heights above the background noise on the $\mathrm{N}$ diffraction pattern. The amount of each mineral was considered to be directly proportional to the peak height. The total of all minerals identified was set equal to $100 \%$.

The $7 \AA$ peak gave the total kaolinite + chlorite; the ratio of these two minerals is deduced from the EG diffraction pattern. Since peak heights also reflect differences in crystallinity between minerals, well-crystallized kaolinite was reduced ( $1 / 3$ less) with regard to other clay minerals. Mixed-layer minerals were corrected in addition to peak height.

The codification used in the text and figures is from Thorez (1975). For simple clay minerals, $C$ denotes chlorite; I, illite; K, kaolinite; and M, smectite. For mixedlayer minerals, 10 denotes 10 - $\AA$ illite; $14 \mathrm{c}, 14-\AA ̊$ chlorite; and $14 \mathrm{~m}, 14-\AA$ smectite (montmorillonite or beidellite). The degree of interstratification is indicated as follows: $(14 \mathrm{c}-14 \mathrm{~m})$ denotes that the interstratified structure is composed of $14 \mathrm{c}$ and $14 \mathrm{~m}$ layers; $(14 \mathrm{c}-14 \mathrm{~m})$, that the underlined member is predominant; $C,(14 \mathrm{c}-14 \mathrm{~m})$, that chlorite appears as a distinct mineral; C - (14c-14m), that chlorite is not distinctly separated from the mixedlayer structures. If such a structure becomes more regular, it is indicated by $(14 \mathrm{c}-14 \mathrm{~m}) \pm \mathrm{r}$.

Results (Fig. 5)

\section{Phyllosilicates}

Identified phyllosilicates are listed in decreasing order: illite (illite-mica), random mixed-layers (mainly chlorite-smectite), kaolinite, smectite, chlorite, and glaucon- ite. Aluminous illites, well crystallized on the whole (Fig. 6), are present throughout the series $(25-65 \%)$. The mixed-layer minerals are composed mainly of chloritelike and smectite-like layers $(14 \mathrm{c}-14 \mathrm{~m})$. The degree of interstratification is variable. In Unit $\mathrm{E}$, chlorite-like components are predominant (14c-14m). In Units D and $\mathrm{C}$ in turn, the smectite member plays the leading part $(14 \mathrm{c}-14 \mathrm{~m})$. Illitic layers were also identified, but they are less important. They alternate with chloritic (10$14 \mathrm{c})$ or smectite layers $(10-14 \mathrm{~m})$ mainly in Subunits E1 and E2, and also, though to a lesser degree, in Subunits $\mathrm{E} 3$ and E4. As regards structure, mixed-layer minerals are more regular in Subunit E3.

Concerning kaolinite, the most conspicuous fact is the contrast between Unit E and the overlying units. Kaolinite is always present in important quantity (up to $40 \%$ ) in Unit E. It is trifling or missing in samples of Units D, $\mathrm{C}$, and $\mathrm{A}$.

Smectites appear as a distinct, well-crystallized mineral in Units A and D, although they are not continuously present. They belong to the dioctahedral series, the two poles of which, montmorillonite and beidellite, are distributed randomly.

Chlorite occurs in Unit E, at the top of Unit C, and in Unit A. In most cases, chlorite is not distinctly separated from the mixed-layer structures: $(10-14 c)-C, C$ $(14 \mathrm{c}-14 \mathrm{~m})$.

Locally, glauconite is clearly visible (glauconitic layers in Cores 549-60 and 549-61 of Unit C; see previous discussion) as granules of silt size or fine sand size $(0.7 \mathrm{~mm})$, without apparent structures. X-ray diffractometry on Sample 549-60-5, 100-102 cm evidenced a 10-Å slightly open and randomly structured glauconite. Oxidizing alteration processes have removed part of its iron to produce goethite.

\section{Other Minerals (whole rock and phase $<2 \mu \mathrm{m}$ )}

Silica. Clastic quartz occurs in sandy and silty fractions, but there is practically no free silica in the $<2-\mu \mathrm{m}$ phase. Clastic quartz may amount to $50 \%$ of sediment in Unit E. It is absent in Subunit D1, reaches 20 to $30 \%$ in Unit C, and again disappears in Unit A (Fig. 2).

Calcite. The percentage of carbonate was measured by the ponderal method with rock powder. It ranges from 98\% (Section 549-67-1) to 3\% (Section 549-90-2). Variations may be large and rapid from one bed to the next. Unit D and Subunit E3 contain the highest percentage of carbonate. Units A and C have less, but are subject to sudden changes.

Dolomite. Dolomite was observed under the microscope and confirmed by diffractograms on powder by reflection (104) at $2.918 \AA$. It makes up $80 \%$ of Unit B (shipboard report). Otherwise, it is confined chiefly to Unit D (Cores 549-72 and 549-75) and also to Subunits E2 (Core 549-83) and E4 (Core 549-93).

Feldspars. After crushing of samples, they are found in small amounts in the $<2 \mu \mathrm{m}$ phase. They are identified by the location of reflection (040), which ranges from $3.177 \AA$ to $3.254 \AA$ (Fig. 7). Microcline and plagioclase are always present, orthoclase more particularly in Units C and D. 


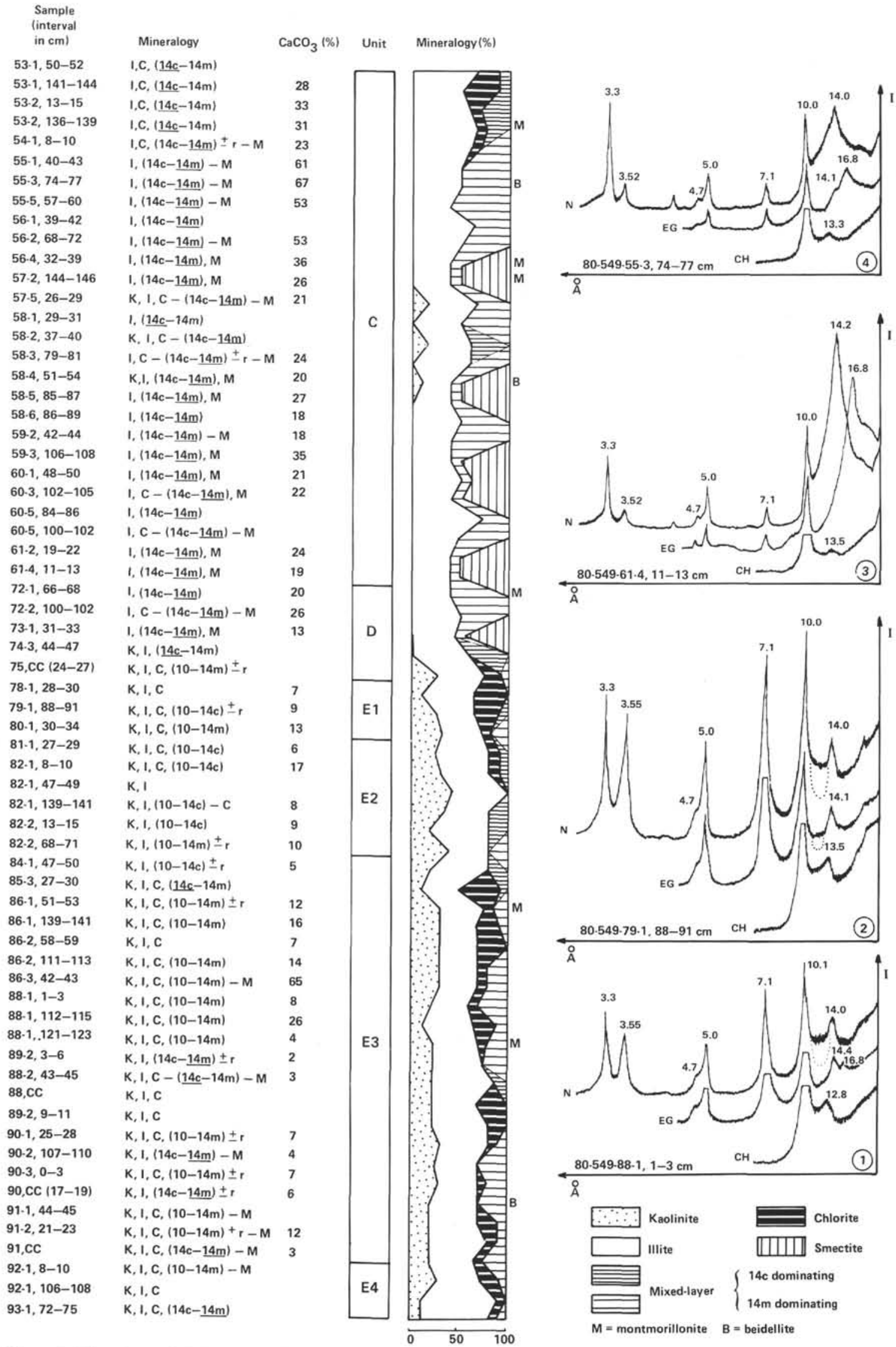

Figure 5. Mineralogy of the $2 \mu \mathrm{m}$ fraction in Units E to C. Diffraction patterns: 1 and $2=$ kaolinite-illite-chlorite and mixedlayer assemblage; 3 and 4 = illite-smectite and mixed-layer assemblage. 


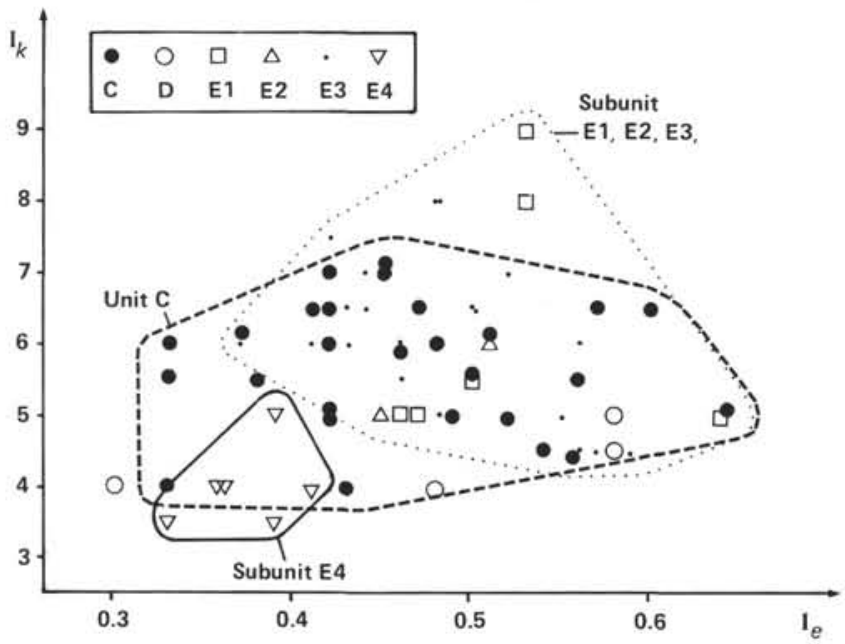

Figure 6. Kubler-Esquevin diagram. $I_{e}=$ ratio of illite peak heights $(001)$ and $(002) . I_{k}=$ width at mid-height above the background noise of illite peak (001).

\section{PALEOECOLOGICAL DATA}

\section{Foraminiferal Assemblages (Fig. 8)}

Precise or sure determinations cannot be obtained, owing to the generally limited number of tests of each species observed in thin sections, their poor preservation, and the planes of sections, which reveal few characteristic views. Thus, only genus or family will be quoted; these suffice to give valuable paleoecological indications.

Foraminifers appear at the base of the Cretaceous series (Section 549-93-1, Subunit E4), but quite sporadically (agglutinated encrusting forms, probably Acruliammina). Stratigraphically, they are distributed in four main types of assemblage, related to four successive facies.

\section{Choffatella and Haplophragmium Assemblages (Cores 549-91 to 549-78, Subunits E3, E2, E1)}

The most conspicuous feature is the scarcity and lack of variety of foraminifers. When the facies is very detritic (silty, sandy) or rich in pyrite and organic matter, they are absent or very rare.

Choffatella is the dominant form, sometimes the only one. It is more numerous in bioclastic facies, and disappears where the terrigenous arrivals are more abundant. Initially small (generally under $1 \mathrm{~mm}$ ), the specimens increase in size from Core $549-89$ to reach $3 \mathrm{~mm}$ or more in some levels (Cores 549-88 and 549-87).

They are accompanied by some large smooth Lenticulina and large Lituolidae (Haplophragmium), several successive forms of which can be identified according to the extraneous material of their tests: quartz grains, carbonate granules, fragments of lamellibranchs at first (Section 549-89-2), then only large quartz grains (part of Core 549-89 to Core 549-87), and lastly carbonate granules and agglomerates of varied small foraminifers (Cores 549-83 to $549-80$ ).

At successive levels (especially Sections 549-91-1 and 549-84-1) in higher-energy facies, sometimes revealing reworking, the microfauna is richer and more varied: Miliolidae (particularly Quinqueloculina), various Atax-

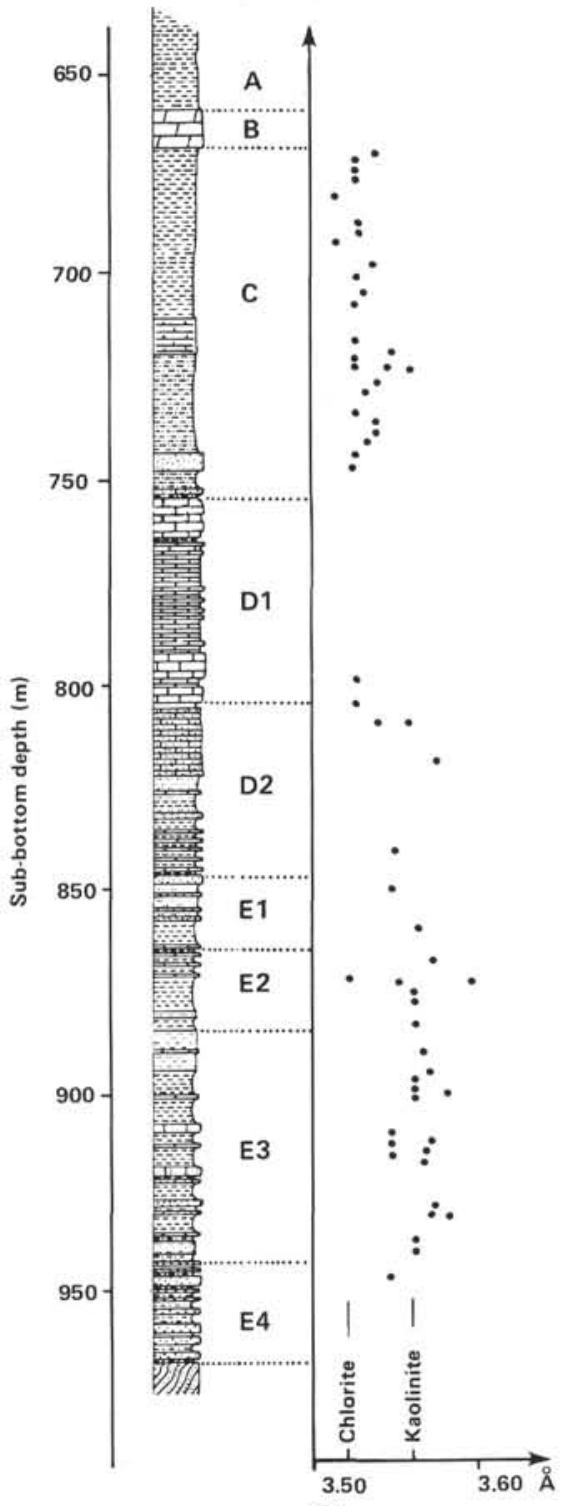

(1)

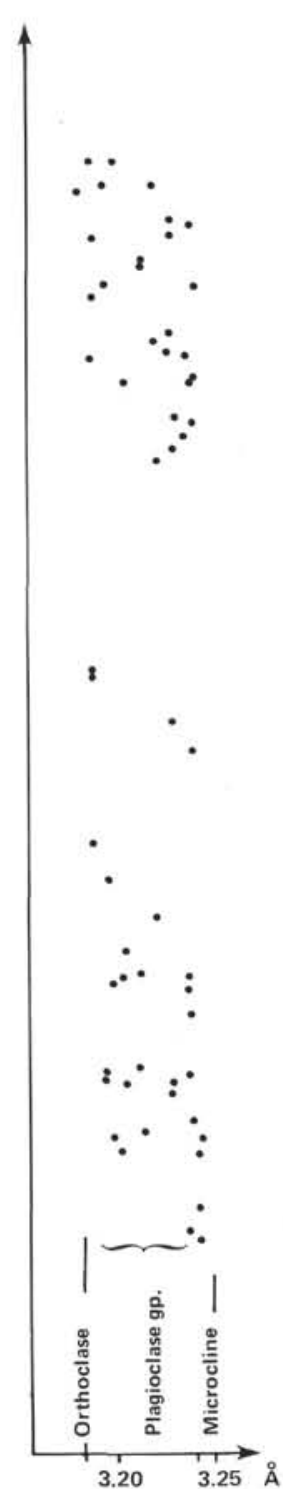

(2)
Figure 7. Locations of reflections (002) of kaolinite, (004) of chlorite, and 040 of feldspars.

ophragmiidae with calcareous microgranular tests (Dorothia, Marssonella, Nezzazatinella), small hyaline rotaliforms?, Polymorphinidae, Trocholina. A comparable enrichment is observed in Subunit E1; the population of foraminifers, more diversified, including in particular Trocholina, is transitional with the following assemblage.

\section{Trocholina and Encrusting Foraminiferal Assemblages (Cores 549-76 to 549-67 and perhaps Core 549-62, Unit D)}

There are foraminifers in all samples. They are definitely more numerous and more diversified than in the facies below. Again, the few poorer beds are more detritic (siltstones). Trocholina prevails (reaching 0.8-0.9 mm), usually in large populations. Choffatella, belonging to the same forms as in the preceding assemblage, sometimes large $(3 \mathrm{~mm})$, is associated with Trocholina, but 
P. RAT, E. GILLOT, F. MAGNIEZ, A. PASCAL

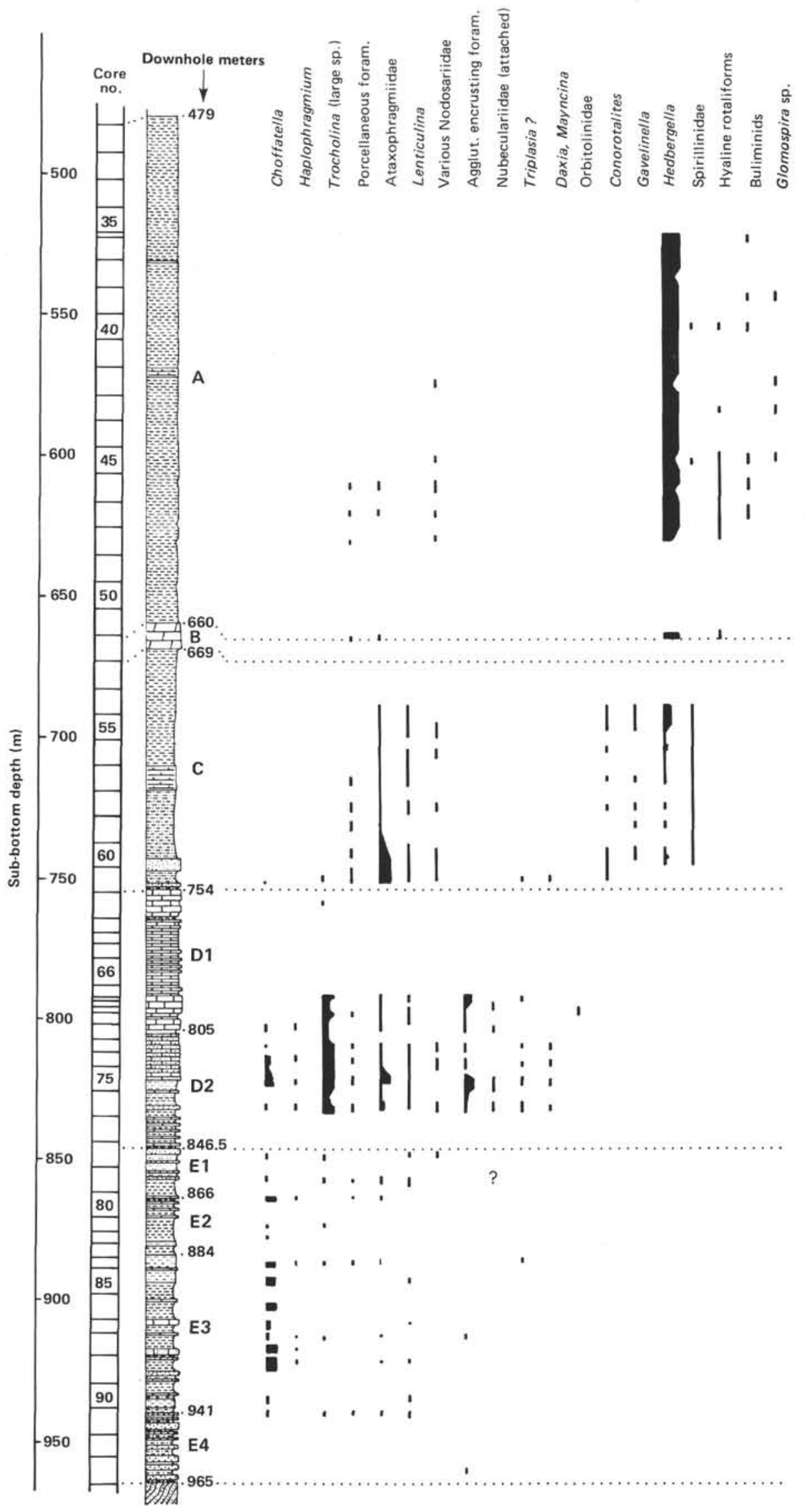

Figure 8. Vertical distribution of foraminifers. 
occurs more sporadically and in much less abundance. It disappears in bioclastic limestones devoid of terrigenous elements at the top of Unit C (Cores 549-70 through 549-67).

In decreasing order, the list also includes Ataxophragmiidae (Dorothia, Marssonella, Gaudryina?, Tritaxia, Belorussiella), Nodosariidae (large Lenticulina and occasionally other genera), and Miliolidae (rare ill-preserved Quinqueloculina); the rarest is Meandrospira. Among lituolids, several large forms of Haplophragmium occur. The majority have carbonate tests in which small foraminifers and calcite spheres are agglutinated. Those containing quartz grains are less common. There are also smaller forms (i.e., Daxia, Mayncina), and probably a large Triplasia. Rare Glomospira were also identified.

Encrusting foraminifers also make up a conspicuous feature of these assemblages. However, they are found essentially in carbonate layers (i.e., oncolitic limestones in Core 549-95, bioclastic limestones in Subunit D1): first agglutinating (mainly Coscinophragma, Acruliammina, Placopsilina), then porcellaneous forms of the nubeculariid family, and at last, calcareous hyaline forms, probably of the Bullopora type. In Core 549-75, in which oolitic and oncolitic facies are striking, foraminifers, especially Trocholina, have been used as nuclei. Encrusting tests themselves are coated, sometimes by several generations of encrusting organisms. As regards orbitolinids, only two or three specimens were seen in thin sections 4 and $5 \mathrm{~b}$ of Section 549-70-1.

No fundamental difference appears in the compositions of assemblages between silty bioclastic limestones in Subunit D2 and porous bioclastic limestones in Subunit D1. In the latter, however, Choffatella has disappeared and the populations of Haplophragmium are distinct. Thin sections seem less fossiliferous, probably because large bioclasts are frequent (coral fragments), and because tests have undergone dissolution and micritization.

\section{Small Benthic Foraminifers Associated with Rare Hedbergella (Cores 549-61 to 549-54, Unit C)}

All samples are fossiliferous. Foraminifers are plentiful and most diversified in Cores 549-61 and 549-60. Cores 549-59 to 549-55 (in its lower part) are not so rich in either number or variety. Populations are richer again in Cores 549-55 (upper part) and 549-54.

The main feature of this third type of assemblage is the reduced size of specimens: none reaches $1 \mathrm{~mm}$; on average, benthic forms are 0.2 to $0.5 \mathrm{~mm}$ in diameter, whereas planktonic forms remain generally under 0.15 $\mathrm{mm}$.

Hedbergella occurs only at the top of Core 549-61, allowing a separation into two types of assemblage, as follows.

First type (at the base, Core 549-61): very abundant ataxophragmiids, no Hedbergella. In these assemblages, composed exclusively of benthic forms, ataxophragmiids were thriving: Dorothia, Marssonella, Gaudryina, Tritaxia, and Falsogaudryinella. Some Textularia are also present. Porcellaneous foraminifers appear regularly:
Quinqueloculina, Cyclogyra, etc. Hyaline calcareous forms include Lenticulina and other nodosariids (Lingulina, Pseudonodosaria, Astacolus), and Conorotalites, which are a marking and new component of the assemblages, although scarce and sporadic; other minute rotaliforms (Valvulineria?), polymorphinids?, and Trocholina and Choffatella specimens occur locally with coral fragments, which are possibly reworked.

Second type (from Sample 549-61-1, 34-36 cm): Hedbergella and Conorotalites. The striking feature here is the first occurrence of planktonic forms. Core 549-60 (siltstones with granular glauconite) still contains ataxophragmiids, varied but in decreasing number, and scarce porcellaneous foraminifers (Conorotalites). Two new groups make their appearance at almost the same time: on the one hand Hedbergella, still rare and very small (80-150 $\mu \mathrm{m})$, on the other hand Gavelinella. In addition, Spirillina regularly occur, as well as Patellina and very small Trocholina.

From Core 549-59 to Core 549-55 in part (fine siltstones), the fauna is impoverished, the same forms becoming scattered. When foraminifers are again abundant, at the top of Core 549-55 and in Core 549-54, families are distributed in slightly different proportions. Ataxophragmiids seem more numerous, whereas Conorotalites and Gavelinella are regularly present, and above all, Hedbergella increases in both number and size (more than $0.2 \mathrm{~mm}$ ). This growing importance of planktonic forms coincides with finer, more clayey sediments.

\section{Hedbergella Assemblages (Core 549-52 to 549-36, Unit A)}

Planktonic foraminifers here play a prominent part. Hedbergella prevails. They are very numerous and range in size from 20 to $200 \mu \mathrm{m}$; in some layers they can even reach 250 to $300 \mu \mathrm{m}$.

Few benthic foraminifers are left: small hyaline rotaliforms, some ataxophragmiids and porcellaneous forms (mostly in the lower part), various nodosariids, scarce Pleurostomella, Spirillina, and Patellina. In addition, small hyaline forms cannot be identified accurately (Praebulimina?, Neobulimina?, Cassidella?, Gubkinella?). From Core 549-45 upward, a large Glomospira, with finely arenaceous test, is ubiquitous.

This planktonic assemblage is associated with Albian fine laminated marls. The number of Hedbergella decreases when the facies abounds in sponge spicules or in calcitized radiolarians (e.g., Samples 549-48-1, 29-31 cm; 549-46-3, 29-31 cm; 549-45-3, 41-44 cm; and 549-38-1, 31-34 cm).

Complementary illustrations concerning these associations are included in the chapter by Magniez and Sigal (this vol.).

\section{Paleoecological Interpretations: Foraminifers}

Choffatella and Haplophragmium assemblages are related to shallow seawater. However, the lack of diversity and the primacy of only one agglutinated species (Choffatella decipiens) are indices for slightly restricted environments and perhaps lowered salinity. 
Trocholina and encrusting foraminiferal assemblages still indicate shallow waters but normal marine salinity. Their success, the great number of specimens, and the faunal diversity, evidence very favorable living conditions (temperature, salinity, food supply, water oxygenation, and so on): infralittoral (= inner littoral) zone of light. The fact that agglutinated tests are built essentially with calcareous particles, and the frequency of Trocholina, fit in with a carbonate-platform environment. Trocholina plus Coscinophragma indicate a position on the outer platform in this paleogeographical pattern.

The occurrence of Hedbergella and small calcareous benthic foraminifers, and the diversification of hyaline forms, show more open marine conditions and greater depth (circalittoral $=$ outer littoral zone).

The composition of the fauna and the nature of the sediment are linked. The richer foraminiferal content in Cores 549-61 and 549-60 coincides with a coarser and more considerable terrigenous influx, which may be a sign of more agitated and more oxygenated waters. Conversely, the relative faunal impoverishment in the overlying cores could have been brought about by more turbid waters and finer silty sediments.

Assemblages in which Hedbergella throve prove a widely open marine environment, but the high percentage of planktonic foraminifers argues for bathyal depth.

\section{Algae and Charophytes}

Practically all the observed calcareous algae are part of the bioclastic fraction in Units E and D, except a few probably reworked fragments at the base of Unit C. They are very abundant in some layers, especially Girvanella and Permocalculus. In addition to specimens generically determined, oncolites-which, according to general opinion, are partly constituted by algae-have also been recorded.

\section{Blue-Green Algae (and Schizomycophyta)}

These are found mainly with the Trocholina assemblages. Girvanella (Unit D, base of Unit C) appears as filamentous structures in some oncolites and in coatings of bioclasts (i.e., coral fragments). According to Masse (1976), Girvanella is typical of cryptic, poorly lit environments. Unidentified Spongiostromata also play a part in oncolitization. These oncolites are very abundant in Unit D (especially in D2), much less abundant in Subunits E1 and E2.

\section{Red Algae}

Permocalculus (Unit E). In a given thin section, fragments may be very numerous and large (1-3 mm). They may have originated from the breaking up of populations living in situ or only slightly transported. They are related to silty-sandy layers rich in organic matter and associated with other algae (Boueina, Diversocallis) and with Choffatella and Haplophragmium.

Diversocallis (Unit D) is rather scarce. It encrusts coral fragments in bioclastic limestones containing siliceous sponge spicules and grains coated by foraminifers and Girvanella.
Archaeolithothamnium (Unit D). Present but not common with Trocholina assemblages in calcareous bioclastic facies lacking quartz. They lived with bryozoans, sponges, echinoderms, lamellibranchs, gastropods, and Diversocallis.

Solenopora (base of Unit E). Rare. Their small hemispheric colonies, made of calcareous tubes, have fallen into pieces, and lie in micritic sandy layers with bryozoans and encrusting foraminifers.

\section{Green Algae}

Boueina (Unit $\mathrm{E}$ and $\mathrm{D}$ ) occur in moderate abundance in poorly sorted silty-sandy facies, rich in organic matter, with Permocalculus and Diversocallis, Choffatella, worms, and lamellibranchs. These photophile algae need strong light concentrations, and are good indicators of shallow clear water (infralittoral $=$ inner littoral zone).

\section{Charophytes}

A few charophyte gyrogonites have been observed in Subunit E3. They originated from fresh or brackish water, but were sedimented with Choffatella and Boueina. It has already been mentioned, in studying foraminifers, that Choffatella assemblages could tolerate lowered salinity. In our opinion, life environments for Choffatella and Boueina on the one hand, and charophytes on the other, were distinct, although close to each other. In any case, both indicate a fresh-water influx and probably polyhaline conditions in a shallow littoral environment.

\section{Paleoecological Interpretations: Algae}

Algae, mainly green algae, corroborate the conclusions based on foraminiferal data. Organisms of Units $\mathrm{E}$ and D lived in shallow well-lit water (infralittoral zone). The occurrence of some charophytes with Choffatella in Subunit E3 confirms a very littoral position and presumably local or temporary variations in salinity (hypohaline water).

\section{Sponges}

Three main types of sponges have been identified in thin section. In the first two cases, their elements are not disconnected; in the third case, only spicules are preserved.

Calcareous sponges (Pharetronidae) occur in limestones and quartzitic limestone of Units E and D, principally with Trocholina assemblages, bryozoans, corals, and serpulids. A specimen of Barroisia (sphinctozoarian), millimetric in size, was seen at the base of Subunit D1.

Siliceous sponges (Hexactinellidae) are frequent in sparitic limestones with Trocholina and encrusting foraminifers, chiefly in Unit D and the base of Unit C. The associated fauna is very diverse: numerous bryozoans, Diversocallis, Archaeolithothamnium, Girvanella, Choffatella, and corals.

As for disintegrated siliceous sponge spicules, they are still siliceous or calcitized, or occur as cavities with a siliceous framework. Typical of Unit A, they are common in assemblages rich in Hedbergella, which also include siliceous radiolarians and debris of echinoderms. 


\section{SEDIMENTARY AND BIOLOGICAL ENVIRONMENTS: CHARACTERISTICS AND ORGANIZATION}

Differences and variations observed in the facies, in the nature and compositions of the rocks and in their biological contents, can be explained by reference to a limited number of homogeneous and well-defined biosedimentary environments, or life and sedimentation environments, inasmuch as organisms which provided the debris lived, if not at the exact place where they are found, at least in the immediate vicinity, as proved by the consistency of biological assemblages and the nature and condition of the fragments. It can reasonably be concluded that benthic organisms were buried near their place of life.

Each of these basic environments includes a homogeneous region of the seafloor, an association of living forms which inhabited it, and water that lay above it. The nature of the seafloor is inferred from the composition, granulometry, and sedimentary structures of its material. The populations are characterized by the nature, abundance, and arrangement of organisms. The water, sustaining life and directly or indirectly providing sediments, varies in salinity, dynamics, degree of light.

In a first approach, basic environments are recognized and described; then they are placed relative to one an- other and in the regional sedimentary pattern. Numbers of subheadings in the following discussion correspond to number designations in the subsequent section titled "The Biosedimentary Pattern" and those on Figure 9 and Plate 1.

\section{Basic Biosedimentary Environments (Plate 1)}

\section{Shallow Environments Under Control of Terrigenous Input}

\section{1a. Silty-Sandy Bottoms with Choffatella}

These are very common in Subunit E4, but also occur in the other subunits of Unit E and in Unit D. The sedimentary material is terrigenous. Life must have been meager, because indices of bioturbation and biological marine remnants are very scarce. Only Choffatella specimens, very scattered, have been seen. Fairly well preserved, larger than the surrounding clastic components, they must have been fossilized in their habitat.

Hence the inference that this first group of facies corresponds to soft, unstable, finely sandy or muddy bottoms without continuous biological cover. On the other hand, several arguments led to the conclusions that the Choffatella substrates were subject to influxes of fresh water. The monospecific population argues for a restricted environment with possible fluctuations of salinity. The ex-

Morphology

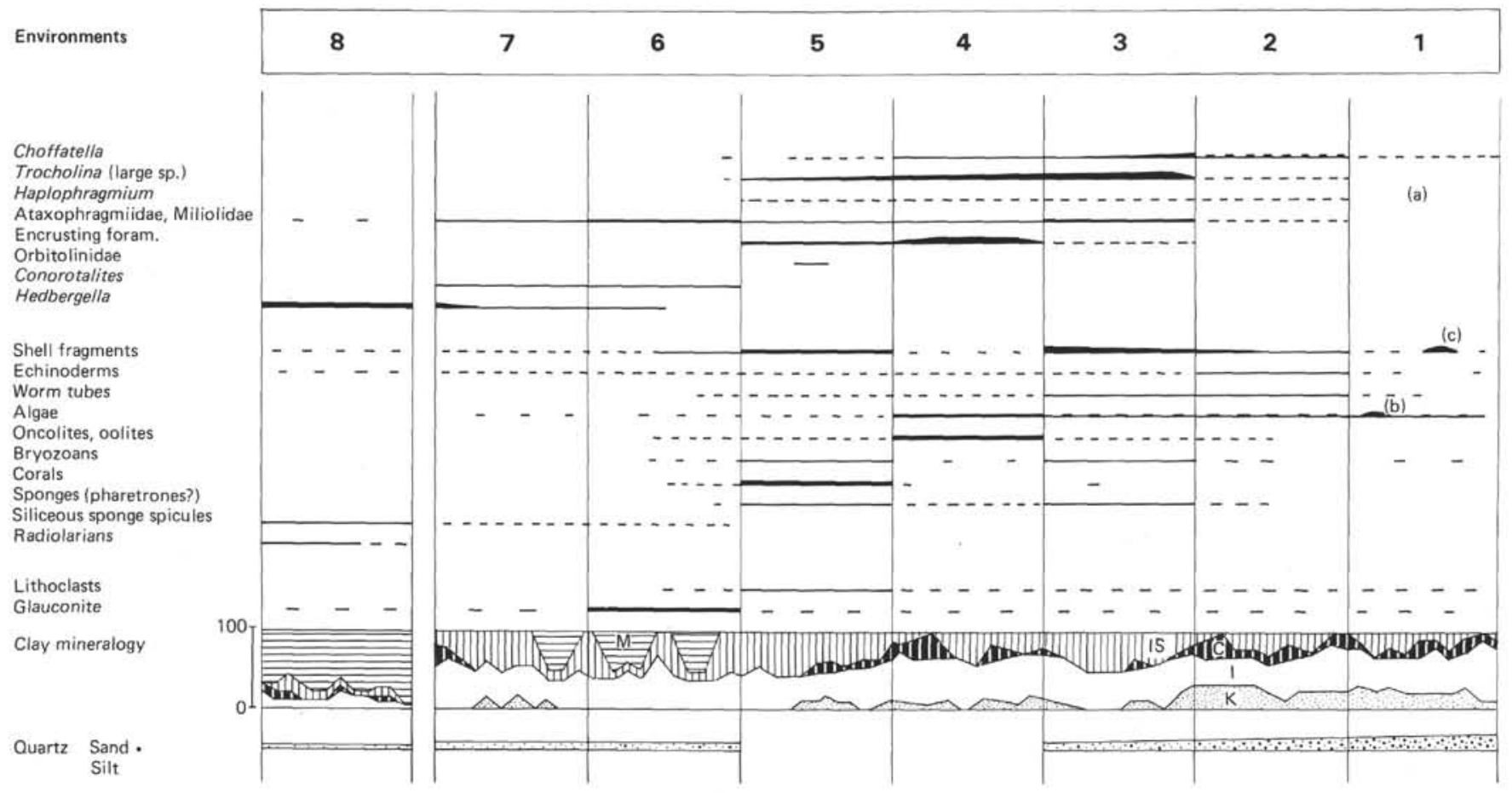

Figure 9. Biosedimentary patterns (see also Plate 1 ): 1 to $8=$ elementary biosedimentary environments (see text). Clay minerals: $\mathrm{C}=$ chlorite, $\mathrm{I}=$ illite, IS = interstratified (mixed-layer) minerals, $\mathrm{K}=$ kaolinite, $\mathrm{M}=$ smectite. 
istence of unindurated bottoms without complete biologi$\mathrm{cal}$ settlements favors regular water influxes carrying a fine terrigenous load. Moreover, Choffatella is known to have lived readily in channels of the submarine shelf (ArnaudVanneau, 1980).

\section{1b. Silty-Sandy Habitats with Red and Green Algae}

The most striking difference from the preceding group is that the seafloor was colonized by algal communities. Calcareous algae, the only ones to be preserved, rather numerous, were doubtless accompanied by forms without hard skeletons. Permocalculus (rhodophytes), broken down but not transported, make up the most conspicuous member. Foraminifers are those of Choffatella and Haplophragmium assemblages.

These facts indicate a colonization especially by algae attached to or rooted in the sediment, a certain stabilization of the bottom, less persistent terrigenous arrivals, and better hold of living creatures. All this was still taking place in shallow water, well penetrated by light, this time without any lowering of salinity.

\section{1c. Silty-Sandy Habitats with Oysters}

In our sampling, the facies bearing oysters is exceptional (in Subunit E3), but it deserves attention. It is remarkable for the abundance of fairly big $(2-\mathrm{cm})$ fragments of oyster shells. In Section 549-85-2, they are well preserved and angular; this allows us to infer a local origin. In Section 549-90-2, they are more blunt. There are practically no Choffatella.

\section{2-5. Environments with Lime-Secreting Benthos (identified in Unit D)}

A coarse bioclastic sand is the sedimentary material preserved here. In some cases, there is no terrigenous fraction. Such rich and varied bioclastic material implies that living organisms colonized readily and modified the seafloor, taking advantage of the absence of terrigenous pollution. To some degree, different populations, more or less homogeneous, growing in close propinquity or associated, are intermingled. Grains are poorly sorted, a confirmation of little transportation.

Only a generalized picture of the seafloor can be formed, however. Attached organisms (corals, bryozoans, brachiopods, sponges, algae, some lamellibranchs and echinoderms) or free organisms (gastropods, lamellibranchs, echinids) lived on a substrate made of their own debris. Foraminifers could develop, either free on the unoccupied parts of the sandy bottom or fixed on other living organisms or their debris. Burrowers may well be responsible for the absence of sedimentary structures. Owing to its probable destruction and in all likelihood to periodical reworking, the initial patchwork of habitats and communities cannot be deciphered from what is left.

According to the fauna and flora, salinity was normal, lighting good (inner littoral $=$ infralittoral photic zone). The grainstone or rudstone texture involves a high water energy. Some micritic geopetal filling would indicate the local trapping of calcareous mud in a relatively stabilized sand. No sign of emersion was observed, how- ever. Likewise, if fixed organisms - that is, potential builders, especially corals-existed, there is no evidence of real buildups. The existence of a carbonate platform with dense benthic population can be ascertained, but no true reef system.

Among these facies, dominated by benthic calcareous production, several categories have been distinguished, as follows.

In the most perfect case, sedimentation is entirely calcareous. The fauna is extremely varied; fragments of corals and bryozoans abound. Terrigenous clastics are lacking and, in correlation, or so it seems, Choffatella are also missing (5 on Fig. 9 and Plate 1).

The oncolite facies offers spectacular thin sections: Envelopes are often complex, built by algae (Girvanella), various foraminifers (Acruliammina, Coscinophragma, Nubecularia), and bryozoans. The area was rather agitated, but terrigenous particles are still nonexistent (4 on Fig. 9 and Plate 1).

Where terrigenous elements occur, the biological content still testifies to an important and varied settlement of the seafloor. It must be thought that we are still at the very place where biological production originated, with occasional terrigenous contamination not sufficient anyhow to disturb the benthic inhabitants appreciably ( 3 on Fig. 9 and Plate 1). Contamination was not necessarily due to direct terrestrial arrivals, but could have been brought about when material on silty-sandy floors happened to be reworked (from silty-sandy habitats with Choffatella). The fact that Choffatella is actually to be found in those facies favors that interpretation. It is also an argument on behalf of the coexistence, next to each other, of silty-sandy unstable bottoms and habitats completely settled by benthic organisms.

As the amount of terrigenous impurity increases ( 2 on Fig. 9 and Plate 1) at the expense of the bioclastic content, the latter is poorly preserved. In Section 549-89-2, for instance, only small shell debris are present, most of them altered into micrite or spar. The micropaleontological suite with Choffatella and Haplophragmium concerns silty-sandy floors. Therefore, the silty-sandy floors are believed to have received supplies of well-sorted and already evolved bioclastic sands.

In other cases, the proximity and influence of populated carbonate areas are unquestionable. Bioclasts still reflect the density and diversity of the original settlement (bryozoans, echinoderms, worms, sponges, Trocholina). A few oncolites and even a few oolites can occur, but they are in a poor state of preservation. The foraminiferal assemblage may also be considered as a mixture: Choffatella on the one hand, Trocholina and in places (Section 549-91-1) even an appreciable amount of miliolids and microgranular agglutinating foraminifers, on the other.

\section{6-7. Clayey-Silty Floors with Scanty Benthic Settling and Open Sea Influences}

In these facies, identified in Unit $C$, terrigenous elements again played a prominent part (as in 1), but in a more sheltered environment, deeper and completely marine. 
Detrital deposits are finer, with a higher proportion of clay. Kaolinite, considered as a direct continental contribution, is missing. In its place, smectites are found.

Benthic life was quite active: lamellibranchs, brachiopods, echinoderms, sponges, and small foraminifers are present. In contrast with the bioclastic facies (type 2-3), the composition of the fauna suggests a discontinuous settling on an unconsolidated bottom, rather stable, however, because water above was calm. Here and there, lamination, giving evidence of fine and quiet sedimentation, is preserved, and in other places it has been disturbed by bioturbation. Algae have not been observed.

Lastly, an outstanding feature worthy of mention: Planktonic foraminifers (Hedbergella) made their way into these sedimentary environments. Some belemnite fragments have also been observed. Thus, an open-sea environment (outer littoral $=$ circalittoral) is confirmed (7 on Fig. 9 and Plate 1).

Some facies (6 on Fig. 9 and Plate 1), located at the base of Unit C, have a mixed character, intermediate between 7 on the one hand, 4-5 on the other. They will be examined apropos of the sedimentary pattern.

\section{Argillaceous Habitats with Hedbergella and Radiolarians (Unit A)}

The most salient fact is the high proportion of planktonic organisms: foraminifers, radiolarians, and, in calcareous strata, nannofossils.

Water energy was weak. The terrigenous phase is mostly argillaceous. Silt-sized quartz grains are rare or absent. The sedimentary structures are fine parallel laminations.

Benthic life was comparatively reduced, little varied, though not negligible: echinoderms, lamellibranchs, brachiopods, siliceous sponges. Bioturbation is often visible.

These environments, with flourishing planktonic organisms, are typical of open sea, above the calcite compensation depth. The water was deep and dark, and benthic calcareous production was weak. Deposition was dependent on the influx of fine argillaceous and siliceous material and a rain of decaying plankton.

\section{The Biosedimentary Pattern}

In the course of describing the various basic environments, we have already mentioned some of their relationships (such as their possible coexistence in more or less close propinquity). It is now possible to take another step and assign a coherent place to them in one sedimentary pattern. A model will thus be constructed which may be said to be "virtual" because, if all its elements were present at Site 549, they were not all present at the same time. This model will be a guide toward understanding the paleogeography and its probable evolution.

The various environments are arranged in the following order, from littoral to open sea (Fig. 9 and Plate 1):

Shallow-water platform: inner littoral (= infralittoral) environments. 1 and 2: Areas of continental influx (fresh-water input, clastic load, terrestrial plant debris), silty-sandy bottoms more or less stable. Possibly channels with Choffatella (1a), soft habitats colonized by al- gae (1b) or oysters (1c), areas supplied with allochthonous bioclastic products from the outer platform (2).

3 to 5: Environments with lime-secreting benthos and bioclastic bottoms. Terrigenous pollution is still perceptible in 3 , but not in 4 and 5 , which correspond to the outer part of the platform with high water-energy and maximal biological production: oncolitic facies (4), bioclastic facies (5).

Open shelf: outer littoral (= circalittoral environments. 6 and 7: Clayey-silty floors with scanty benthic settling and open-sea influence. Facies 6 is interpreted as a mingling of 5 and 7, located on the platform slope.

External pelagic basin: bathyal environments. 8: Argillaceous bottoms with planktonic rain.

\section{VERTICAL EVOLUTION AND ITS IMPLICATIONS}

\section{A Transgressive Sequence, a Quickening of Subsidence}

It is worth emphasizing that the vertical succession of facies, in spite of the break introduced by the dolomitic Unit B (Borkowski and Mazzullo, this vol.), strictly reproduces the biosedimentary order ranging from littoral to open sea, from very shallow environments to bathyal depths.

In this vertical succession, correlation between lithologic units (E to A) and environment types (1 to 8 ) is as follows. The sequence ( $=$ transgression) begins (Subunit E4) on a basement, probably Paleozoic, by clearly marine but very marginal (near-shore) environments. The area was mobile, well supplied with land-derived sediments, and inhabited only sporadically by a few benthic populations.

The whole of Unit E reflects littoral environments with continental influences (environments of type 1). These influences are confirmed by the composition of the acid-resistant organic matter (Batten et al., this vol.): megascopic remains of land-plants, abundant gymnosperm pollens. However, the marine benthos manage to colonize at least temporarily in Subunits E3-E1 (environments $1 \mathrm{~b}$ with algae, $1 \mathrm{c}$ with oysters). In addition, there are signs (facies 2 ) that nearby carbonate-platform environments with bioclastic production were already in existence.

These environments of benthic biological carbonate secretion (4 and 5), which did not lead to reef construction at Site 549, give Unit D its peculiarity. The permanence of more littoral environments, displaced toward the continent by the transgression, is indicated by mixed (3) or recurring facies (1a and 1b). (Advance of marginal terrigenous environments on the carbonate platform.)

Unit $\mathrm{C}$ corresponds to environments 6 and (particularly) 7 , which mark a deepening of the sea. The existence of intermediate facies (6) at the bottom of the unit may be explained by a rather progressive deepening. Unit A corresponds to environments (8) obviously deeper and more distant from the littoral; they received only very fine terrigenous particles; the bulk of the biologic sedimentation was planktonic. 
There is still uncertainty regarding the significance of Unit B, which is not dated paleontologically, and of the discontinuity revealed there by downhole measurements. How were the outer littoral environments (7, Unit C) replaced by bathyal environments ( 8 , Unit $\mathrm{A})$ ? What is the explanation of the stratigraphic gap between Unit C, assigned to the Barremian, and Unit A, Albian? It must be acknowledged that, in spite of the break brought about by the dolomitic Unit B, and perhaps by a lowered sea level accompanied by subaerial erosion, Unit A, of deepsea origin, curiously appears as the continuation of the Barremian evolution (transgressive sequence and subsidence revealed by the underlying series $\mathrm{E}-\mathrm{C}$ ).

As a matter of fact, the thickness (exceeding $200 \mathrm{~m}$ ) of the Barremian series of shallow environments (Units $\mathrm{E}$ and $\mathrm{D}$ ) implies that the main cause of transgression and sediment accumulation was a regional subsidence and not just a eustatic rise of sea level. In the beginning (Units E and D), subsidence (which was very likely slow), plus eventually a rise of sea level, were compensated for by sedimentation, and depth of water was maintained in the infralittoral photic zone. With Unit C, and still more with Unit A, the rate of deepening (subsidence) exceeded that of accumulation.

\section{Inferences Drawn from the Terrigenous Input}

The clastic material (silt and sand) is very mature, almost exclusively reduced to quartz. This implies that it was supplied from a chemically very decayed source, such as a much-weathered cover.

Information derived from clay minerals leads to the same conclusion. Two different assemblages have been identified (Fig. 5): the first is characterized by kaolinite (Unit E), the second by a predominance of smectite (Units D, C, and A).

1. Kaolinite-illite-chlorite assemblage. Kaolinite (up to $40 \%$ of the $<2 \mu \mathrm{m}$ fraction) and illite (up to $30 \%$ ) are the main minerals, associated with chlorite and predominantly chloritic mixed-layer minerals: C - (14c-14m), $(14 \mathrm{c}-14 \mathrm{~m}),(10-14 \mathrm{c})$. This assemblage indicates a typically detrital origin: weathering of crystalline or metamorphic rocks, or slates or shales (illite, chlorite) more or less combined with pedogenesis (chloritic mixed-layer minerals, kaolinite) (Chamley, 1979a and b). This conclusion is in accordance with conclusions based on paleobotanical evidence (Batten et al., this vol.): "The overall composition of the spore, pollen, and plant debris assemblages indicates that the depositional site was relatively close to land clothed in a mixed pteridophytegymnosperm vegetation."

Kaolinite is a fairly good marker of hot and humid climate and of weathering in a well-drained environment. The maturity of the silty-sandy phase is consistent with such a type of climate. Study of the acid-resistant organic matter leads to the same conclusion: "a climate probably similar to that of the Wealden area of southern England during the Hauterivian and Barremian; that is, warm temperate and relatively moist" (Batten et al., this vol.).

2. Illite-smectite-mixed-layer assemblage. Smectite or predominantly smectitic mixed-layer minerals character- ize this second assemblage, of which they generally make up more than $50 \%$. Illite is always there, in even higher proportions than in the first assemblage. On the other hand, kaolinite is present in only a few samples. Whether smectite formed in a submarine or subaerial environment is questionable. Smectite can have various origins (Chamley et al., 1978): degradation in welldrained soils in mild climates, neoformation in badly drained soils in hot climates with contrasting seasons, sedimentary formation in a basically chemically confined environment, or by subaerial or submarine transformation of volcanic material.

The assemblage of smectite with detrital illite, with smectitic chloritic mixed-layer minerals, and occasionally with kaolinite, greatly favors a detrital origin. The occurrence of the smectite assemblage in Units D, C, and A, that is to say in different environments (4 to 8 ), is more evidence favoring the argument.

The replacement of kaolinite by smectite would then correspond to a change in the composition of the terrigenous supply. What can have been the cause of such a change? The first hypothesis is that the climate was modified; the second, simpler, implies a shift of the supply area in consequence of a local change (from tectonic origin) in the continental relief and the drainage system. Final choice requires more data from other localities.

\section{COMPARISONS AND CONCLUSIONS}

In short, in the history revealed by the lower part of Series 549, three successive paleogeographic phases are recorded: a short transgressive episode in a shallow environment (Barremian); the beginning (Albian) of a long period of pelagic sedimentation in a bathyal environment; and, in between-corresponding to a gap in sedimentation, incompletely filled up by Unit B-a period during which a paleogeographic and structural rearrangement took place.

The general trend of evolution is in accordance with what is known in other points of the Biscay Bay margins, particularly on the southern margin (northern margin of the Iberic Plate), where our knowledge is founded upon the study of extensive exposures (Cretaceous Basco-Cantabrian country: Fig. 1) which can be deciphered more thoroughly (Rat et al., 1982) as follows:

1. First period: breaking up of blocks and early sinking of a passive plate margin. Rates and amounts of movement were different according to blocks. Subsidence was counterbalanced by sediment accumulation, so that the environment was maintained slightly below sea level. Subsidence of blocks favored limited marine ingressions and the occurrence of facies similar to Units E to C.

The most typical exemplar is the Trocholina and bryozoan facies found in Ramales, south of Santander (Rat, 1962; Salomon, 1982). It is about 10 m.y. older (approximately Berriasian) than the Site 549 facies. The bioclastic limestones at Ramales contain rounded debris of bryozoans, echinoderms, sponges (Plate 3, Fig. 4), encrustings of agglutinated foraminifers (Plate 2, Fig. 6), complex oncolites (Plate 2, Fig. 7), and Trocholina. It is a similar very shallow carbonate-platform environment, but, like Unit D, not a coral reef. It too is mixed with 
more marginal environments, with a greater load of terrigenous sediments. Exposures allow tracing of a lateral passage southwestward (Vega de Pas) to more detrital formations closer to emerged land.

A second comparison can be made with the Cantabrian Urgonian systems (Aptian-lower Albian; Pascal, 1982). As a result of the unequal movements of blocks, shallow-water carbonate platforms (as in Unit D but with different fossil assemblages, rudists and orbitolinids) could exist alongside somewhat deeper, limited basins. Deposits of these basins, in an outer littoral environment, are to be compared with Unit C: terrigenous arrivals, sponge fauna, occurrence of planktonic Hedbergella (Magniez and Rat, 1972).

This pattern quite agrees with the picture of a distended continental margin undergoing rifting and thinning by the relative movement of blocks.

2 . Second period: Increased subsidence exceeds sedimentation in the distal part of the margin. Presumably this distal part was separated by a slope (see the foregoing and Fig. 9) from the proximal part (continental shelf). Its pelagic sediments may be compared with Unit A. Both are Albian. The difference is to be found in the terrigenous influx, which, at the foot of the slope, is revealed by turbidite intercalations or accumulations (black "flysch" of the Basque Albian series). This is a typical case of subsidence of a passive margin when the oceanic accretion has begun.

The essential difference between the trend revealed by Site 549 and the trend observed in the Basco-Cantabrian country is to be found in the transition between the two paleogeographic patterns of the margin. In northern Spain, the formations belonging to the second period often lie in apparent continuity, and only mapping shows a discordance. At Site 549, there is a gap between Unit C, the last of the first period, and Unit A, by which the second period begins. This break includes at least the duration of the Aptian stage, even if small dolomitized Unit B was to be assigned to the Aptian. What happened during that time? Just nondeposition? Or subaerial erosion resulting from crustal uplift or a sea-level lowering? The hypothesis of a crustal uplift does not seem to fit with the environmental and sedimentary evolution. However, a sea-level lowering could have interrupted the continuity of an environmental evolution without significant change in the subsidence, if the rate of lowering was higher than the rate of subsidence. The information provided by Site 549 alone does not allow a decision.

\section{ACKNOWLEDGMENTS}

At this stage, there is one more thing to do, and a pleasant one. We wish to express our thanks to those who helped us: P. C. de Graciansky, who gave us the opportunity to participate in the DSDP research and spared no encouragements or assistance. Our contacts with him and with J. Sigal were friendly and profitable.
The reviewers, R. C. Bathurst and B. Purser, carefully read and corrected the manuscript according to the rules of the Board of Editors. Such valuable help and advice is greatly appreciated. Devoting time and attention to a text originally written in French by four different geologists, and then translated, was a delicate task. If the English is still difficult, the responsibility is the authors' alone.

J. Gras (SNEAP) interpreted the well logs; Thiry (École des Mines de Paris) helped in X-ray analyses of the Albian. A. Godon made the photographs of the plates. As for Mrs. Rat, she prepared the English text and the typescript.

\section{REFERENCES}

Arnaud-Vanneau, A., 1980. Micropaléontologie, paléoécologie et sédimentologie d'une plate-forme carbonatée de la marge passive de la Téthys: l'Urgonien du Vercors septentrional et de la Chartreuse (Alpes occidentales). Geol. Alpine, 11:790.

Chamley, H., 1979a. Les successions argileuses de l'Atlantique Nord, écho des changements mésozoïques de l'environnement. Exemple du bassin du Cap Vert. Compt. Rend. Acad. Sci. Paris, 289-D: 769-772.

, 1979b. North Atlantic clay sedimentation and paleoenvironment since the Late Jursassic. In Talwani, M., Hay, W., and Ryan, W. B. F. (Eds.) Deep Drilling Results in the Atlantic Ocean: Continental Margins and Paleoenvironments. Am. Geophys. Union, Maurice Ewing Series, 3:342-361.

Chamley, H., Debrabant, P., Foulon, J., d'Argoud, G. G., Latouche, C., et al., 1978. Mineralogy and geochemistry of Cretaceous and Cenozoic Atlantic sediments off the Iberian Peninsula (Site 398, DSDP Leg 47 B). In Sibuet, J.-C., Ryan, W. B. F., et al. Init. Repts. DSDP, 47, Pt. 2: Washington (U.S. Govt. Printing Office), 429-450.

Evans, C. D. R., Lott, G. K., and Warrington, G., 1981. The Zephyr (1977) wells, South-Western Approaches and Western English Channel. Rep. Inst. Geol. Sci., 81(8):44.

Magniez, F., and Rat, P., 1972. Les formations à Spongiaires et Tritaxia dans l'Aptien-Albien cantabrique (Espagne). Rev. Esp. Micropal., pp. 159-178.

Masse, J. P., 1976. Les calcaires urgoniens de Provence. ValanginienAptien inférieur. Stratigraphie, paléontologie, les paléonenvironments et leur évolution [thèse doct.]. Université d'Aix-Marseille II.

Montadert, L., Roberts, D. G., and Shipboard Scientific Party, 1979. Sites 399, 400 and Hole 400A. In Montadert, L., Roberts, D. G., et al., Init. Repts. DSDP, 48: Washington (U.S. Govt. Printing Office), 35-71.

Pascal, A., 1982. Variations biosédimentaires dans les systèmes urgoniens basco-cantabriques (Espagne). Cret. Res., 3:83-89.

Rat, P., 1962. Contribution à l'étude stratigraphique du PurbeckienWealdien de la région de Santander (Espagne). Bull. Soc. Geol. France, 7:3-12.

Rat, P., Amiot, M., Feuillée, P., Floquet, M., Mathey, B., Pascal, A., and Salomon, J., 1982. Étapes et style de l'évolution de la marge cantabrique et de son arrière-pays (Espagne) au Crétacé. Compt. Rend. Acad. Sci. Paris, 295:247-250.

Salomon, J., 1982. Les formations continentales du Jurassique supérieur-Crétacé inférieur (Espagne du Nord, Chaỉnes Cantabrique et NW-Ibérique). Stratigraphie-Sédimentologie-Cartographie. Relations entre tectonique et sédimentation. Mem. Geol. Univ. Dijon, 6:227.

Thorez, J., 1975. Phyllosilicates and Clay Minerals. A Laboratory Handbook for Their X-ray Diffraction Analysis: Liège (Editions G. Lalotte).

Date of Initial Receipt: December 17, 1982

Date of Acceptance: April 26, 1983 


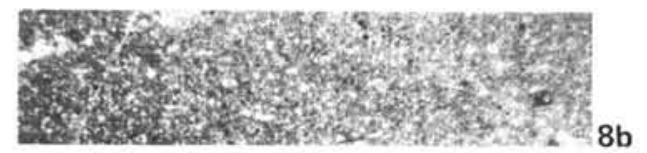

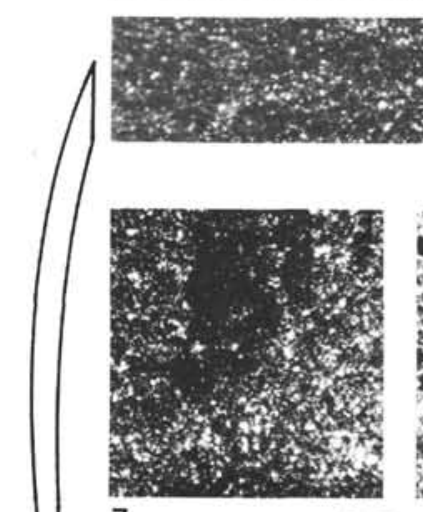

$\left.\right|^{7}$

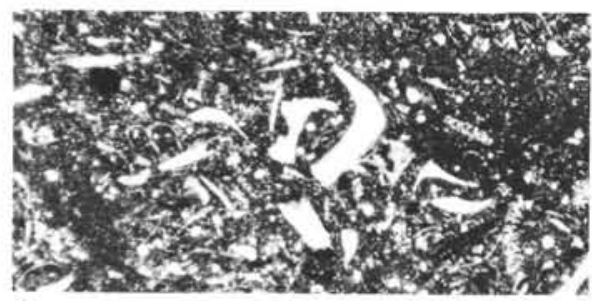

2

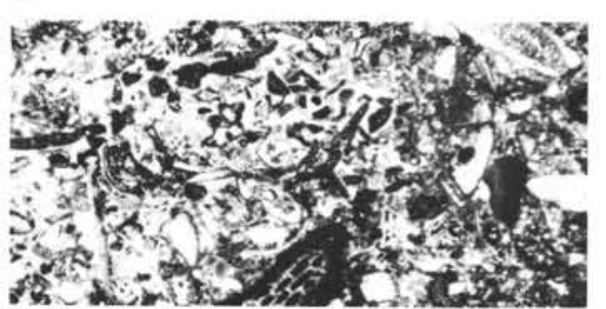

3

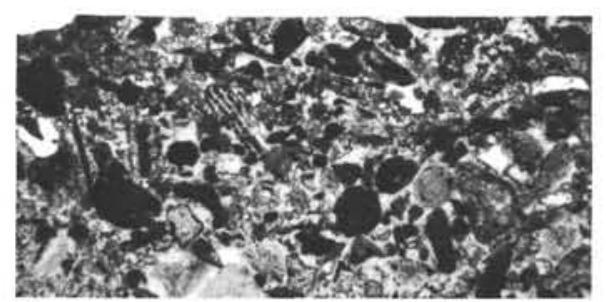

5

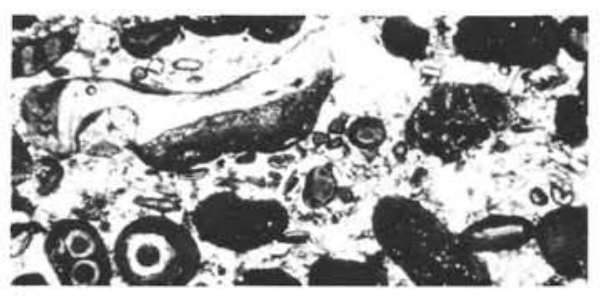

4

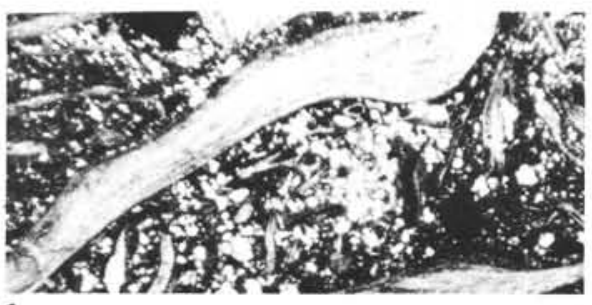
$1 c$

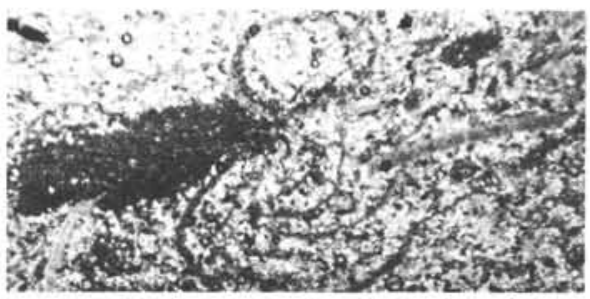

1b

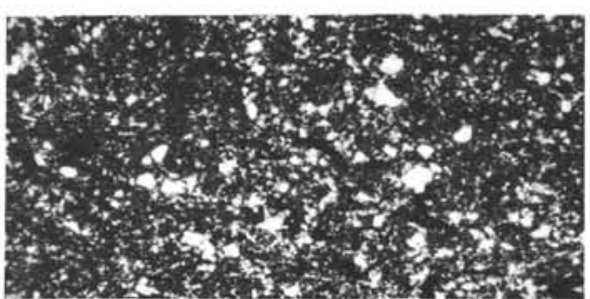

1a

Plate 1. Characteristic facies and their locations on the biosedimentary profile. (All thin sections magnified approximately $\times 6$.) 1. Shallow environments under control of terrigenous input; silty-sandy bottoms, (1a) without microfauna, Sample 549-2-1, 106-108 cm, Barremian, Unit E, (1b) with algae (Permocalculus), Sample 549-78-1, 122-124 cm, Barremian, Unit E, (1c) with oysters, Sample 549-85-2, 80-83 cm, Barremian, Unit E. 2-5. Inner littoral environments with line-secreting benthos, (2) silty-sandy floor with bioclastic input, Sample 549-75-2, 147-149 cm, Barremian, Unit D, (3) facies testifying to a biological settlement with terrigenous input, Sample 549-89-2, 31-34 cm, Barremian, Unit E, (4) oncolitic facies, Sample 549-75-3, 75-82 cm, Barremian, Unit D, (5) entirely bioclastic facies, Sample 549-69 (no. 2), Barremian, Unit D. 6. Mixed facies, clayey-silty floor with glauconite, Sample 549-60-5, 1-5 cm, Barremian, Unit C. 7. Outer littoral environment, clayey-silty floor, Sample 549-58-5, 129-131 cm, Barremian, Unit C. 8. Bathyal argillaceous facies with low carbonate content, Sample 549-47-2, 83-85 cm, Albian, Unit A. 9. Bathyal argillaceous facies with high carbonate content, Sample 549-46-1, $18-20 \mathrm{~cm}$, Albian, Unit A. (For foraminifers, see also Magniez and Sigal, this vol.). 

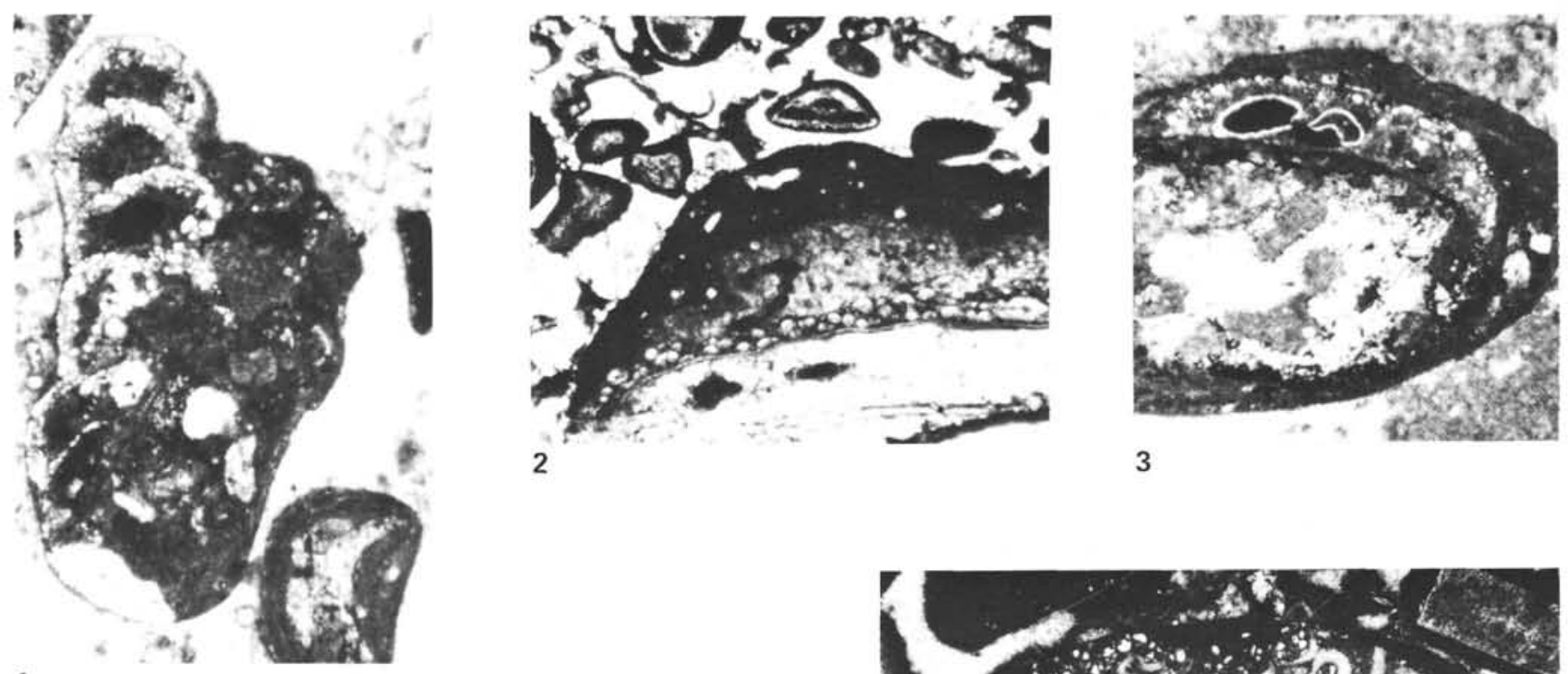

1
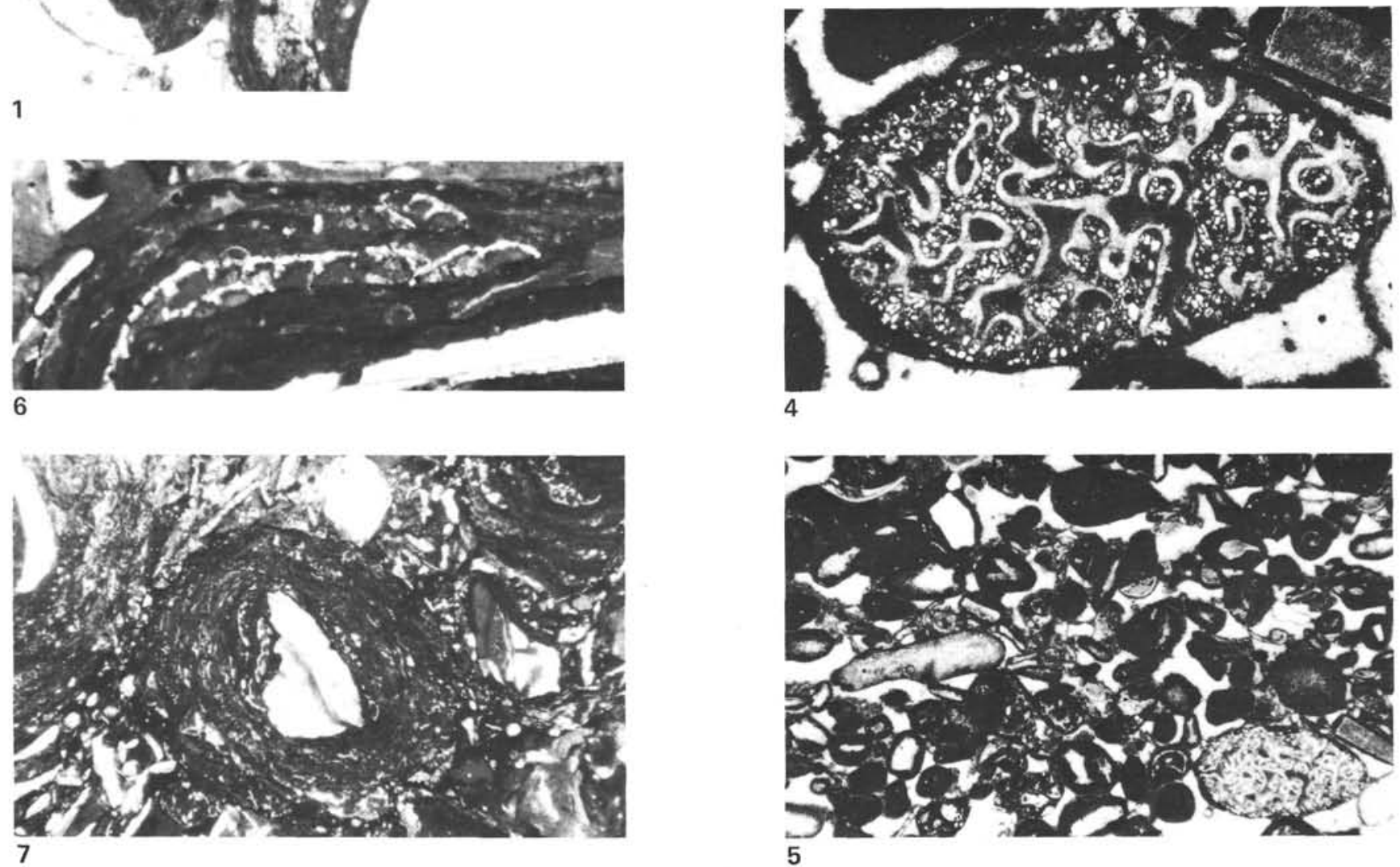

Plate 2. Oncolitic facies from Site 549 (Unit D, Barremian) and from Trocholina and bryozoan limestone at Ramales, Spain (Berriasian). 1,3. Agglutinated-encrusting foraminifer: Acruliammina $(\times 35)$, Sample 549-75-3, 49-51 cm. 2. Complex encrusting: Wetheredella (sparitized area) on Girvanella $(\times 20)$, Sample 549-75-3, 75-82 cm. 4. Coscinophragma $(\times 20)$, Sample 549-75-3, 49-51 cm. 5. Oncolitic grainstone $(\times 6)$, Sample 549-75-3, 49-51 cm. 6. Acruliammina $(\times 35)$, sample from Ramales, Santander Province, Spain. 7. Oncolitic grainstone $(\times 5)$, sample from Ramales. 

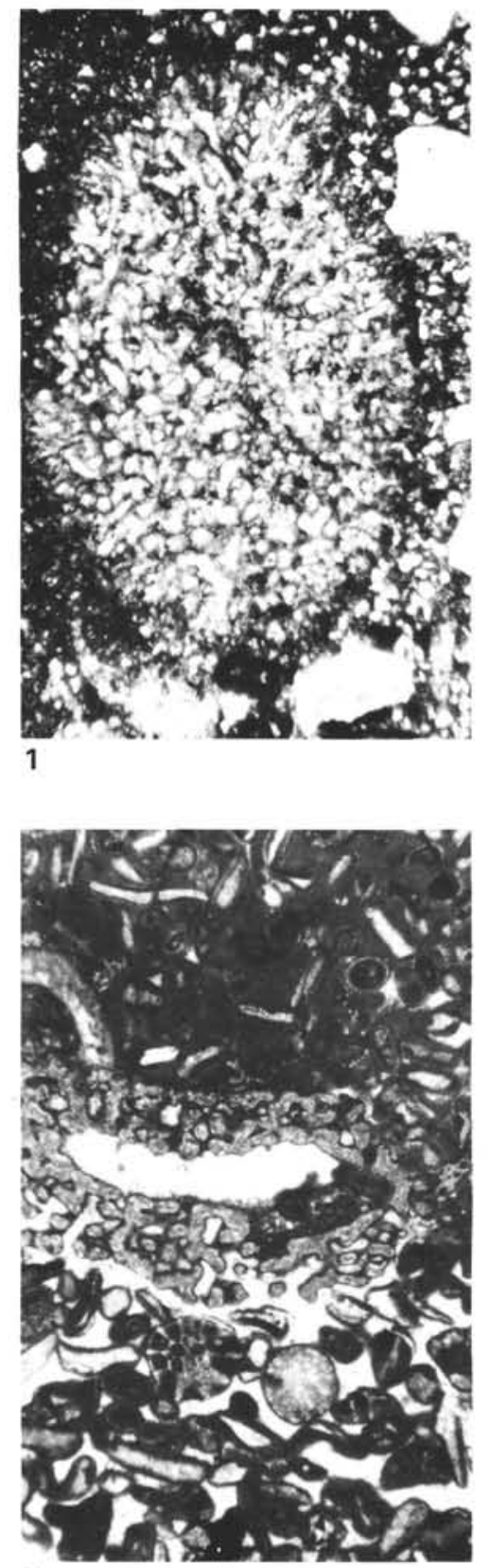

4

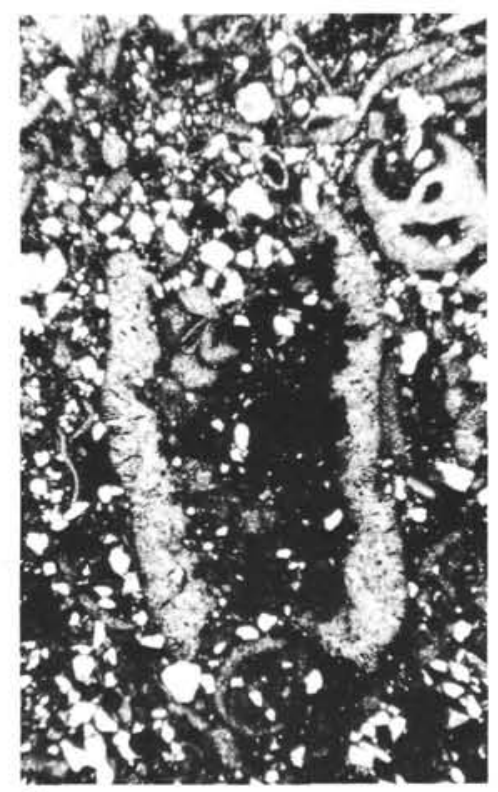

2

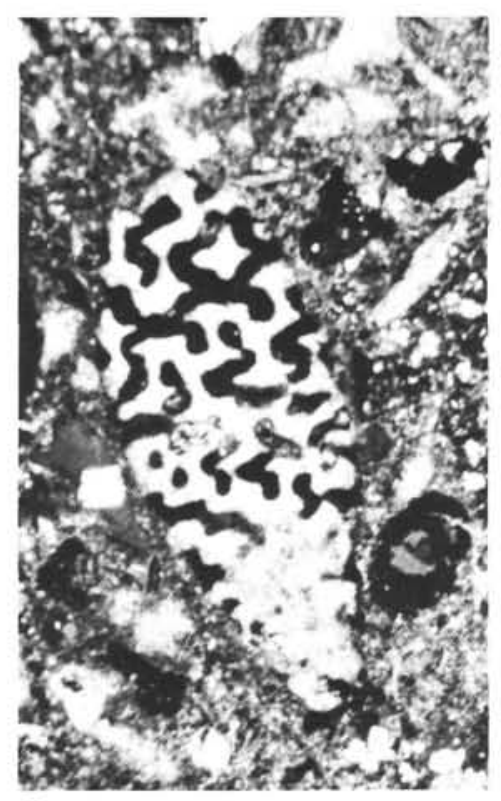

5

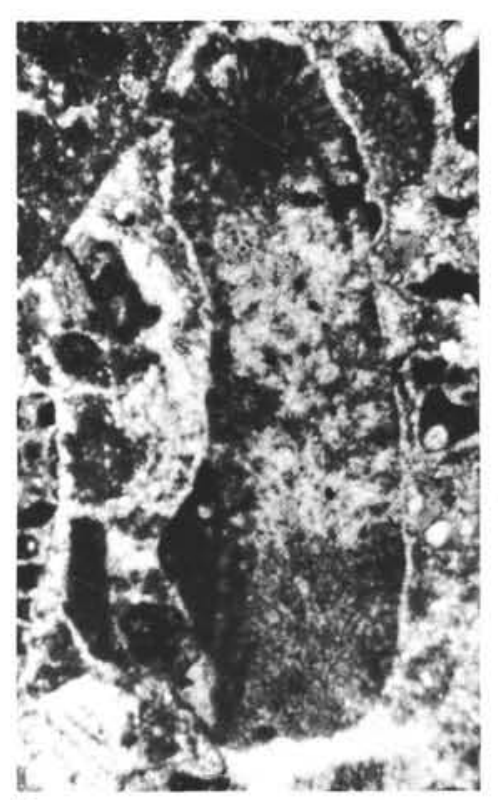

3

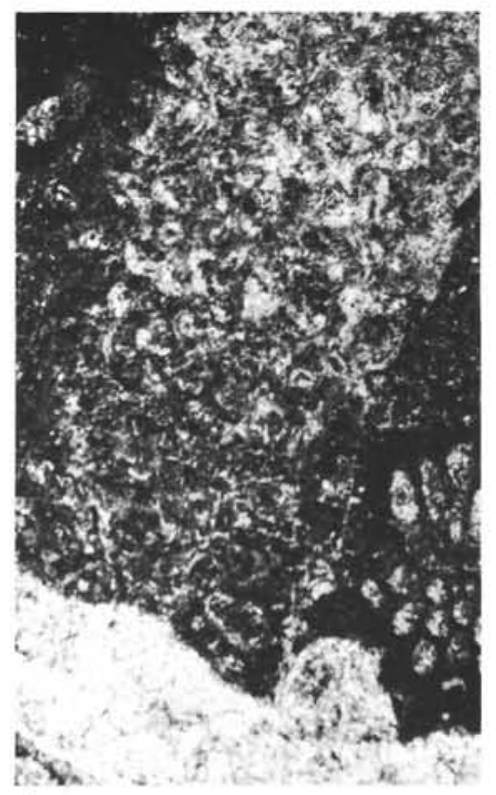

6

Plate 3. Sponges and algae (Barremian). 1. Boueina, green alga $(\times 20)$, Sample $549-90-3,33-36 \mathrm{~cm}$, Unit E, Barremian. 2. Permocalculus, red alga ( $\times 20)$, Sample 549-89-1 (no. 1a), Unit E, Barremian. 3. Diversocallis, red alga $(\times 20)$, Sample 549-67-1 (no. 1a), Unit D, Barremian. 4. Calcareous sponge, Pharetronida $(\times 10)$, Ramales limestone (Spain), Berriasian. 5. Same specimen as Fig. $4(\times 20)$, Sample 549-72-1, 145$149 \mathrm{~cm}$, Unit D, Barremian. 6. Calcareous sponge $(\times 20)$, Sample 549-72-1, 145-149 cm, Unit D, Barremian. 


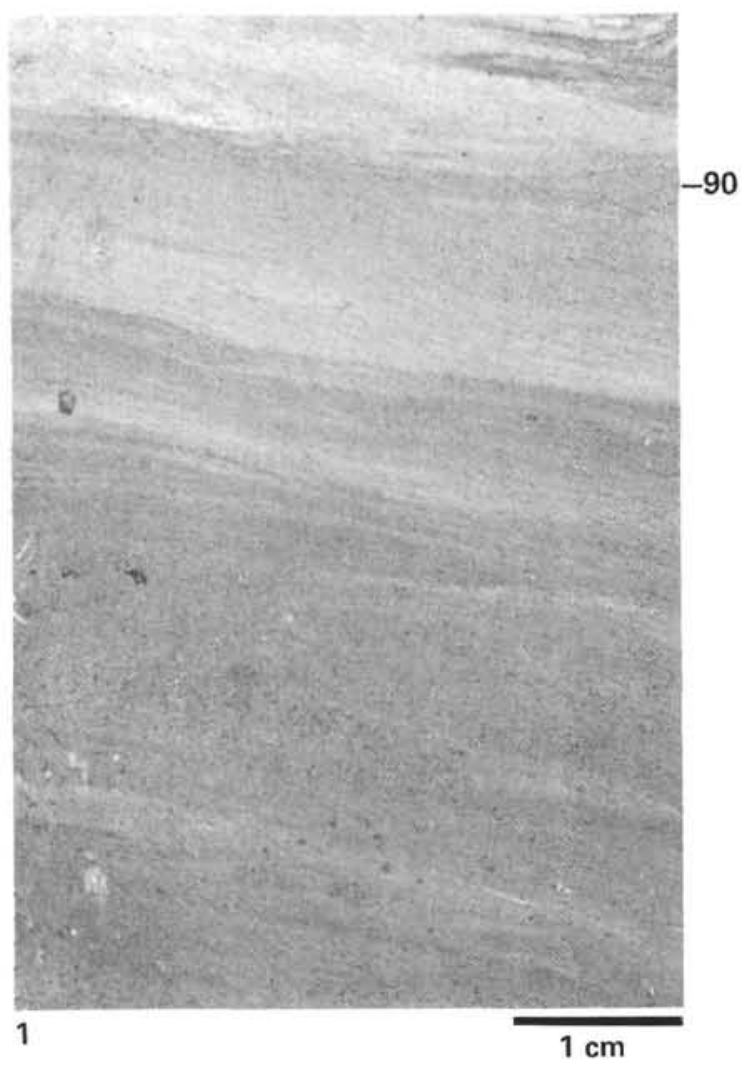

1

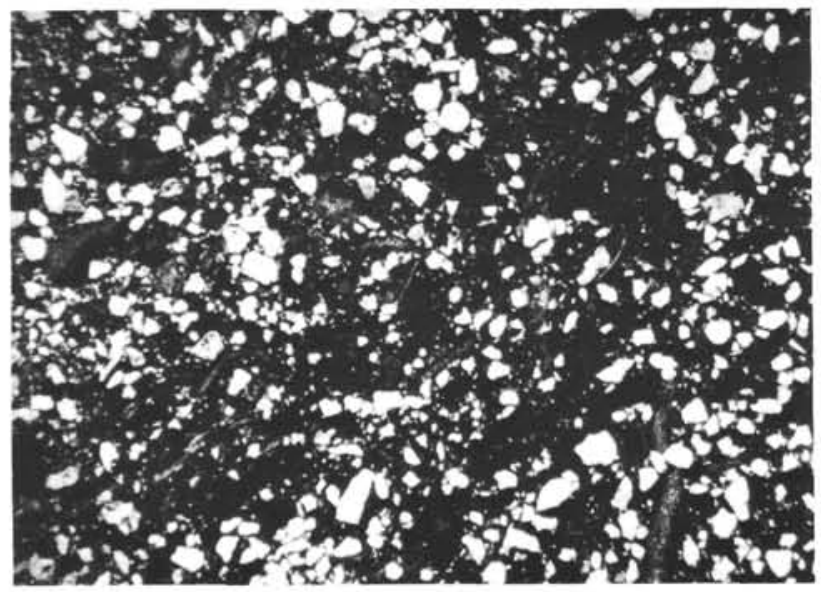

4
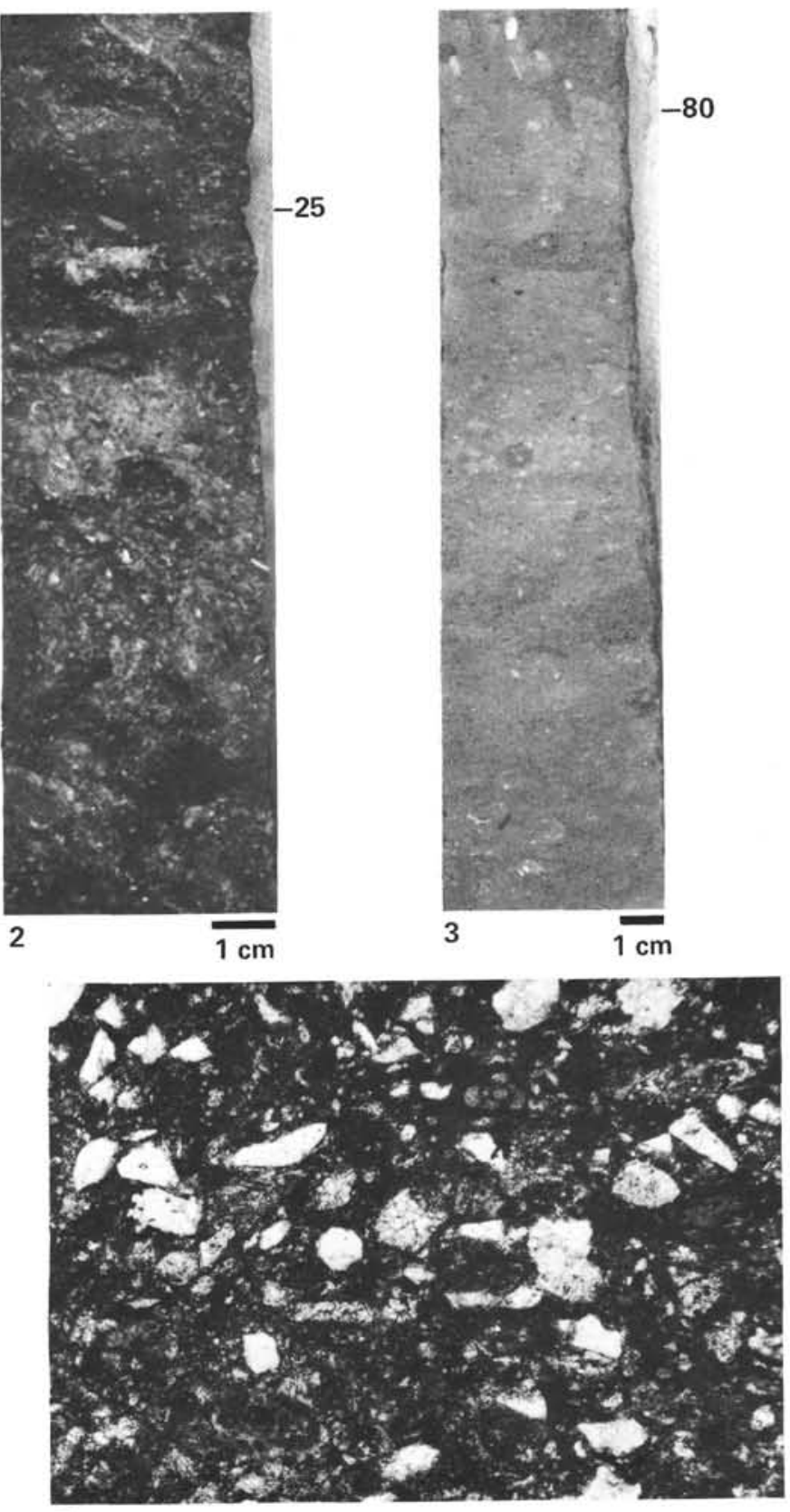

5

Plate 4. Barremian facies and sedimentary features. 1. Parallel laminations $(\times 1.7)$, Subunit E2, Sample $549-82-1,89-95 \mathrm{~cm}$. 2. Strong bioturbation in bioclastic siltstone $(\times 0.6)$, Sample $549-81-2,21-39 \mathrm{~cm}$. 3. Bioturbation in argillaceous siltstone $(\times 0.6)$, Unit C, Sample 549-60-4, $78-101 \mathrm{~cm}$. 4. Siltstone with bioclasts, detail from Figure $2(\times 10)$, Sample $549-81-2,33-36 \mathrm{~cm}$. 5. Siltstone, detail from Figure $3(\times 80)$, Sample $549-60-4,88-91 \mathrm{~cm}$. 